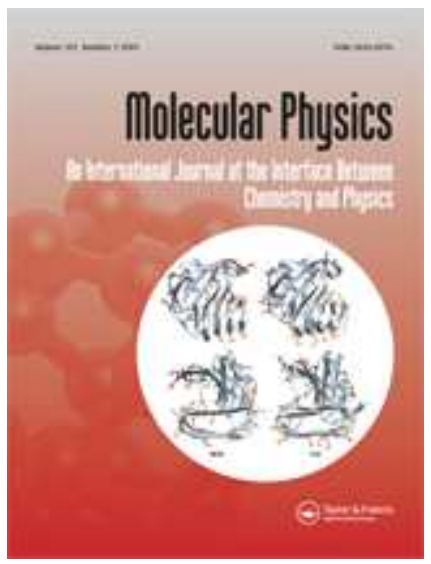

\title{
Computational Study of Redox Active Centers of Blue Copper Proteins: A Computational DFT Study
}

\begin{tabular}{|r|l|}
\hline Journal: & Molecular Physics \\
\hline Manuscript ID: & TMPH-2008-0332.R1 \\
\hline Manuscript Type: & Full Paper \\
\hline Date Submitted by the \\
Author: & 07-Dec-2008 \\
\hline Complete List of Authors: & $\begin{array}{l}\text { Pavelka, Matej; Charles University, Chemical Physics and Optics } \\
\text { Burda, J.V.; Charles University, Czech Republic, Department of } \\
\text { Chemical physics and optics }\end{array}$ \\
\hline Keywords: & $\begin{array}{l}\text { DFT calculations, plastocyanin, blue copper proteins, copper } \\
\text { complexes }\end{array}$ \\
\hline
\end{tabular}

\section{$\checkmark$ ScholaroNE" \\ Manuscript Central}




\title{
Computational Study of Redox Active Centers of Blue Copper
}

\section{Proteins: A Computational DFT Study}

\author{
Matěj Pavelka and Jaroslav V. Burda* \\ Department of Chemical Physics and Optics, Faculty of Mathematics and Physics, \\ Charles University, Ke Karlovu 3, 12116 Prague 2, Czech Republic \\ *Corresponding author, e-mail: burda@karlov.mff.cuni.cz
}

\begin{abstract}
Active sites of blue copper proteins in both reduced and oxidized states were studied at the Density Functional Theory (DFT) level. Two families of these redox sites were examined: the Type A centers with methionine ligand as $4^{\text {th }}$ residue and the Type B with Glutamine residue. Constrained and full optimizations were performed on the protein data bank structures in vacuo and in implicit solvent model simulating protein and water environments. It was found that the redox sites do not possess optimum geometries regardless of the oxidation state. The axial $\mathrm{Cu}$-ligand bond elongates/shortens in the fully optimized $\mathrm{Cu}(\mathrm{I}) / \mathrm{Cu}$ (II) complexes. The reduced centers have a tendency to decrease the coordination number, while a trend to form four "equivalent" bonds is preferred in the oxidized centers. Comparison of the full and constrained optimizations also revealed that the A centers exhibit lower relaxation energies. In the constrained structures, a higher ionization potential was predicted for the A centers when compared to the $\mathrm{B}$ centers regardless of the influence of environment. The calculated relative difference of the redox potentials between various A and B centers is in good agreement with the experimental data. In the fully optimized complexes, the redox properties are dependent on the environment but
\end{abstract}


usually higher IP for the B centers is predicted. Partial charges, MO's, and spin density distributions (obtained by natural population analysis) were analyzed together with calculated electron paramagnetic resonance (EPR) spectra for deeper understanding of the obtained results.

\section{Introduction}

Every sixth entry in the protein data bank (PDB) contains a metal cofactor. Such statistics demonstrate the importance of the metal ions for catalytic processes in a living cell. Hence, investigation of metal sites - such as copper redox centers - is essential for determination of molecular mechanisms in biochemistry. The $\mathrm{Cu}$ ions often exhibit interesting spectral properties, which originate from the unusual geometric and electronic structures that are imposed through their interactions with protein environment. Such proteins provide many functions: electron transfer, oxidation-reduction processes, oxygen transport and insertion, and so forth.

Blue copper proteins forms the so-called Type $1 \mathrm{Cu}$ proteins[1,2]. These $\mathrm{Cu}$ proteins have an intense absorption band near $600 \mathrm{~nm}$ in the oxidized $\mathrm{Cu}(\mathrm{II})$ state. This transition is assigned with the S(cysteine)-Cu Ligand-to-Metal-Charge-Transfer (LMCT). Structures of the active sites usually contain a 4-coordinated $\mathrm{Cu}$ ion, though a coordination number of five was found in azurins. Structural motif consists of the arrangement $\mathrm{Cu}(\mathrm{I}) / \mathrm{Cu}(\mathrm{II}):(\mathrm{His}) 2 \mathrm{Cys} \mathrm{X}$, where $\mathrm{X}$ is Met or Gln. Examples of this motif can be found in pseudoazurin, rusticyanin, plastocyanin, mavicyanin, auracyanin, stellacyanin, umecyanin, and amicyanin. Interestingly, reduction of the $\mathrm{Cu}(\mathrm{II})$ ion to $\mathrm{Cu}(\mathrm{I})$ in type 1 proteins causes minimal structural changes. It results in a low activation barrier for the $\mathrm{Cu}(\mathrm{I}) \rightarrow \mathrm{Cu}$ (II) redox process and thus a rapid electron 
transfer. Very interesting review on these complexes was published recently by Solomon[3].

There is a large number of works investigating biological activity of the copper proteins using both experimental and theoretical approaches. By means of UVVIS and EPR spectroscopy, Cu-center of azurin was studied[4]. Spectroscopic tools in combination with DFT calculations were used to investigate the role of amino acid in axial position to the copper complex and its influence on a reduction potential[5]. Published experimental works include a vast range of techniques, e.g. fluorescence spectroscopy[6], X-ray absorption near-edge structure (XANES) spectra[7][8], combination of EPR and electron-nuclear double resonance (ENDOR) techniques[9], EPR and UV-VIS spectra[10], and many other. The basic aspects of a copper coordination in the protein environment are summarized in reviews[11-14]. Charge transfer (CT) dynamics of the blue copper proteins was investigated using a pumpprobe[15] and resonance Raman spectroscopy[16]. Some other experimental studies dealing with these proteins should be also mentioned[17-19]. Theoretical studies of the copper interactions with amino acids have been reported recently[20-30]. A lot of computational effort was devoted to the examination of copper proteins[31-40]. The first theoretical spectra of plastocyanin were computed by Solomon's group[41,42] and many studies were reported recently, e.g.[43-49]. Calculation of the EPR parameters were published for aqua-ligated $\mathrm{Cu}(\mathrm{II})$ complexes at the modified B3LYP level[50]. Similarly also azurin and some other blue copper proteins were explored[51]. In the case of plastocyanin, QM/MM method was successfully applied[43]. Force-field potentials were developed for $\mathrm{Cu}$-ligand interactions in plastocyanin[52] and applied in the study of LMCT dynamics for this protein[53]. An analogous attempt to construct an empirical force-field for the oxidized form of blue 
copper proteins was made earlier based on DFT calculations[54]. Same authors studied coordination bonds in amicyanin and rusticyanin using QM/MM (IMOMM) $\operatorname{method}[55]$.

A great attention was also paid to examination of the "small inorganic complexes" in order to determine coordination geometries and electronic properties of various copper compounds. Investigation of these small models can provide a deeper insight into and an easier interpretation of the $\mathrm{Cu}(\mathrm{I}) / \mathrm{Cu}(\mathrm{II})$ behavior. Interactions of the both $\mathrm{Cu}$ cations with molecules like water, ammonia, or hydrogen-sulfide were intensively studied by many researchers[56-76]. A more detailed literature discussion on this topics can be found in our previous papers where these complexes were inspected[77-79].

This study focuses on models of active mononuclear centers, which are present in blue copper proteins (e.g. plastocyanin in Figure 1). This study gives a comparison of electronic properties for general tetra-coordinated complexes with the active centers of blue copper proteins (within the fixed-geometry from pdb structures).

\section{Computational Details}

Active sites of the blue copper proteins (Scheme 1) were studied at the DFT level of theory. In the Type A family of the blue proteins (with Met residue), the following protein structures from the PDB database[80] were considered: amicyanin (1AAC), auracyanin (1QHQ), plastocyanin (1KDI and 1KDJ), and rusticyanin (1A3Z and 1RCY). In the case of the Type B centers (with Gln residue), the following proteins were analyzed: mavicyanin (1WS8), stellacyanin (1JER), and umecyanin (1X9R and 1X9U). These X-ray crystal structures were obtained with resolution in range from 
1.33 to $1.90 \AA$ A. Structures of azurin were omitted, since they contain the second axial ligand forming 5-coordinated copper center. This study concerns only 4-coordinated redox centers, where the $\mathrm{Cu}(\mathrm{I}) / \mathrm{Cu}(\mathrm{II})$ cation (Scheme 1) is coordinated with: cysteine, two histidines, and methionine (A centers) or glutamine (B centers).<smiles></smiles>

Scheme 1: The 4-coordinated $\mathrm{Cu}(\mathrm{I}) / \mathrm{Cu}(\mathrm{II})$ redox center of blue copper proteins. Residue $\mathrm{R}$ is either methionine or glutamine.

In the present work, histidine residues were modeled by imidazol, cysteine by the negatively charged methyl-thiolate $\left.\left[\mathrm{S}_{(\mathrm{CH}}\right)\right]^{1-}$, methionine by dimethyl-sulfide $\mathrm{S}\left(\mathrm{CH}_{3}\right)_{2}$, and glutamine by acetylamine $\mathrm{OC}\left(\mathrm{CH}_{3}\right)\left(\mathrm{NH}_{2}\right)$. These models are illustrated in Figure 2.

Structure optimizations were performed at several levels. In the first step (labeled "Constrained optimization"), the PDB structures are used as starting geometries. The $\mathrm{Cu}$-ligand distances as well as orientation of ligands were kept frozen as shown on Scheme $2 \boldsymbol{a}$. This way, the $\mathrm{Cu}-\mathrm{L}$ distances and bonding directions $(\mathrm{Cu}$

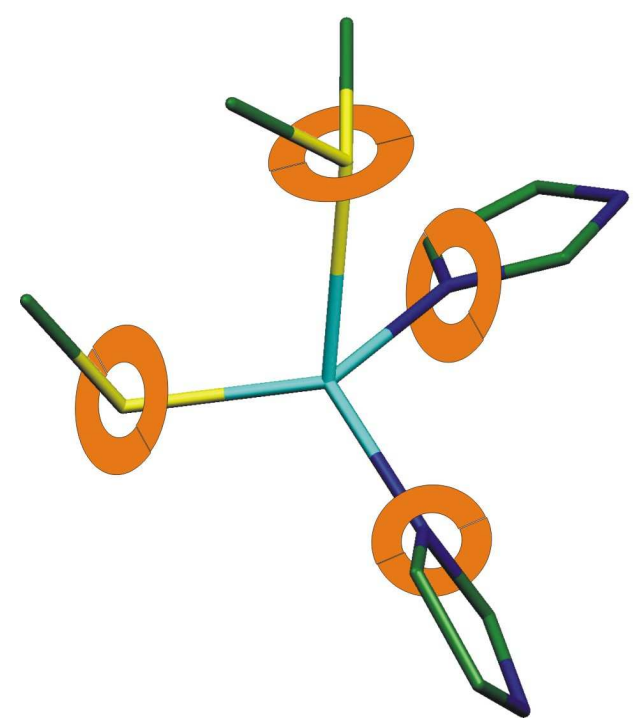

a)
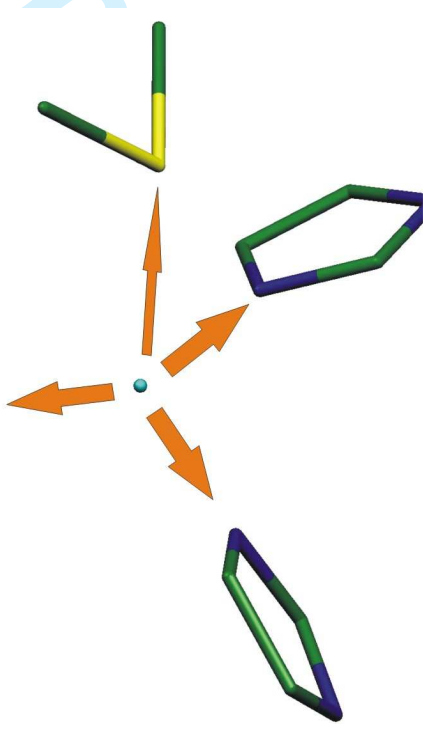
valence angles) of amino acids remain unchanged.

During the second optimization step (labeled "Constrain optimization phase II"), the copper cations could move freely (Scheme $2 \boldsymbol{b}$ ) in the fixed framework of frozen ligands (resulting from the previous optimization phase). In the last step, the full optimization of the whole complex was allowed leading to the reduction of all the Type A centers to one final structure and analogous reduction also occurred in the case of the B centers. Since the second optimization step did not bring any important changes in coordination, it is not considered in further text.

Quantum chemical calculations were performed at the DFT level using the B3LYP functional. For the $\mathrm{H}, \mathrm{C}, \mathrm{O}, \mathrm{N}$ atoms, the $6-31+G(d)$ basis set was applied. The copper core electrons were described by the Christiansen Averaged Relativistic Effective Pseudopotentials (AREP)[81]. A consistent basis set was adopted for the valence electrons. Double- $\zeta$ pseudoorbitals of $\mathrm{Cu}$ were augmented by the diffuse and polarization functions $\left(\alpha_{\mathrm{s}}=0.025, \alpha_{\mathrm{p}}=0.35, \alpha_{\mathrm{d}}=0.07\right.$, and $\left.\alpha_{\mathrm{f}}=3.75\right)$. Similarly, pseudoorbitals of the sulfur atom were extended by analogous functions with exponents: $\alpha_{\mathrm{s}}=0.077, \alpha_{\mathrm{p}}=0.015$, and $\alpha_{\mathrm{d}}=0.50$.

Reduced centers with the $\mathrm{Cu}^{+}$cation were represented by a closed shell singlet electronic ground state, while the oxidized $\mathrm{Cu}(\mathrm{II})$ complexes, where $3 \mathrm{~d}^{9}$ electron configuration is present, possess doublet ground states. Hence, some attention had to be devoted to the correct initial guess for the SCF procedure and the appropriate character of the wave function was checked in the end of every calculation.

All optimizations were preformed in vacuo as well as with inclusion of the solvation effects. The Conductor-like screening model (COSMO)[82,83] was used to simulate two environments: water (with relative permittivity $\varepsilon=78$ ) and protein-like environment $(\varepsilon=4)$. 
Having obtained the optimized structures, further analyses were performed at the higher computational level. More accurate $6-311++G(2 d f, 2 p d)$ basis set was used for the $\mathrm{H}, \mathrm{C}, \mathrm{N}$, and $\mathrm{O}$ atoms. At this level, the Stuttgart ECP pseudopotentials were used for both the $\mathrm{Cu}$ and $\mathrm{S}$ atoms. The basis sets on the copper/sulfur atoms were consistently enlarged by $s p d / s p$ diffuse functions and $2 f g / 2 d f$ polarization functions $\left(\alpha_{\mathrm{f}}=1.00,0.26, \alpha_{\mathrm{g}}=0.66 / \alpha_{\mathrm{d}}=0.92,0.29, \alpha_{\mathrm{f}}=0.57\right)$.

Energy analysis consists of evaluation of stabilization $\boldsymbol{\Delta} \boldsymbol{E}^{S t a b}$ and bond $\boldsymbol{\Delta} \boldsymbol{E}^{\boldsymbol{B} \boldsymbol{E}}$ energies. In these calculations, Basis Set Superposition Error (BSSE) corrections and corrections on the deformation energies[84] were considered according to the equation

eq. (1)

$$
\Delta E^{\text {Stab }}=-\left(E_{\text {complex }}-\sum E_{\text {fragment }}^{\text {BSSE }}-\sum E^{\text {deform }}\right)
$$

where $E_{\text {complex }}$ represents the total energy of the whole complex and $E_{\text {fragment }}^{\text {BSSE }}$

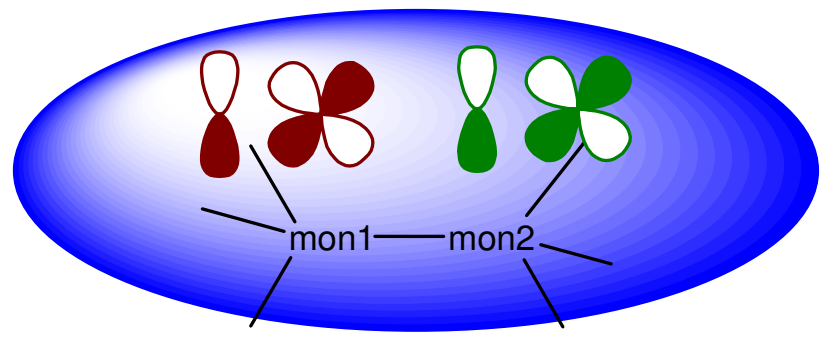

a)

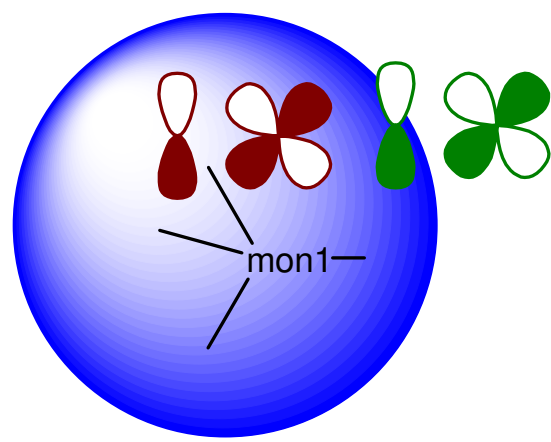

b)

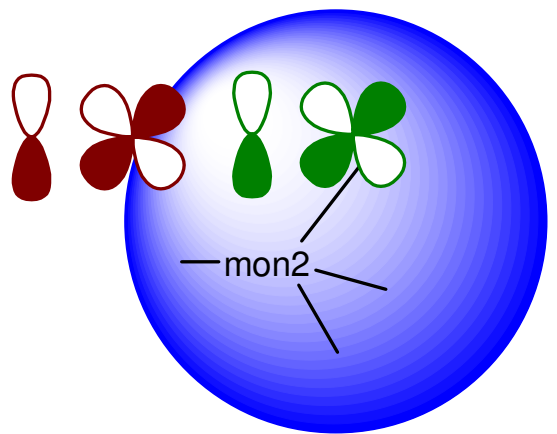

c)

Scheme 3: Construction of boundary between the continuum and the solute within the BSSE scheme. In equation $(\mathbf{1}), \boldsymbol{a})$ represents $E_{\text {complex }}$, while $\boldsymbol{b}$ ) and $\boldsymbol{c}$ ) illustrate

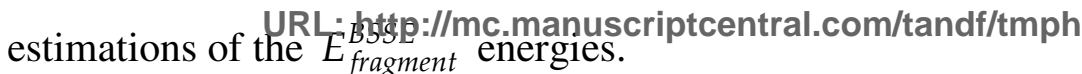


represents the energy of a given subsystem computed with basis functions on the ghost atoms from the complementary part(s) of the system. Deformation energy is a sum of energy differences where for each fragment energy of fully optimized structure and energy of frozen geometry taken from the whole complex are subtracted $\left(E^{\text {deform }}=\underset{\text { fragments }}{\stackrel{\circ}{\mathrm{a}}}\left(E^{\text {optim }}-E^{\text {frozen }}\right)\right.$, using the same number of basis functions for each fragment). In case of the BSSE calculations within the COSMO model, it is not clear how to estimate the $E_{\text {fragment }}^{B S S E}$ energies. In the present work, we propose location of the solvation cavity only around the monomer (Scheme 3), regardless the fact that the basis functions on the ghost atoms are located outside the cavity. In this computational scheme, it is necessary to replace values of the dispersion and repulsion energies, since inclusion of the ghost functions in the BSSE calculations of

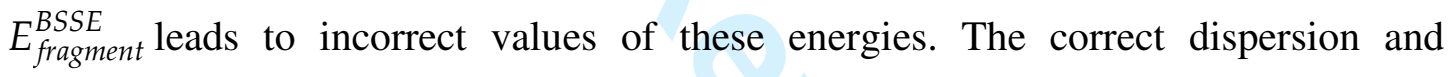
repulsion terms were taken from the single-point calculations of the corresponding deformation corrections (for further details see ref. [85]).

In addition, total coordination energies $\left(\boldsymbol{\Delta E} \boldsymbol{E}^{T C E}\right)$ were also determined. In this case only two fragments were considered in eq. (1): a) all the interacting ligand molecules treated as one subsystem and b) the central $\mathrm{Cu}$ ion as another one. These values can be understood as the binding energies of the cation with a pre-formed ligand shell. In our previous work[77-79], the $\boldsymbol{\Delta} \boldsymbol{E}^{\boldsymbol{T C} \boldsymbol{E}}$ energies were labeled $\boldsymbol{\Delta} \boldsymbol{E}^{\text {Stex }}$. The difference between $\boldsymbol{\Delta} \boldsymbol{E}^{S t a b}$ and $\boldsymbol{\Delta} \boldsymbol{E}^{\boldsymbol{T C} \boldsymbol{E}}$ estimates the energy, which must be invested to form the ligand shell arrangement in the absence of the ion. However, the actual interligand repulsion is larger in the presence of the cation due to the additional polarization effects[86]. 
The $\boldsymbol{\Delta} \boldsymbol{E}^{\boldsymbol{B} \boldsymbol{E}}$ energies of the $\mathrm{Cu}-\mathrm{L}$ ligand bonds were obtained using eq. (1) where partitioning according to $\mathrm{Cu}-\mathrm{L}$ bond must be used. The $\boldsymbol{\Delta} \boldsymbol{E}^{\boldsymbol{B} \boldsymbol{E}}$ values were considered without the contributions of the deformation corrections.

In order to describe redox activity of the studied complexes, vertical and adiabatic ionization potentials (IP) were calculated for the reduced $\mathrm{Cu}(\mathrm{I})$ centers according to formula:

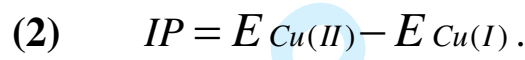

In the case of the vertical IP, the $\boldsymbol{E}_{\boldsymbol{C u}(\boldsymbol{I I})}$ term represents the energy of a (2+) charged system calculated in the $\mathrm{Cu}(\mathrm{I})$ optimized structure. For the adiabatic IP, the $\boldsymbol{E}_{\boldsymbol{C u}(\boldsymbol{I I})}$ energy was determined from the $\mathrm{Cu}(\mathrm{II})$ optimized structure.

The charge and spin distributions were analyzed in terms of partial atomic charges and spin densities were obtained by the Natural Population Analyses (NPA)[87]. Spin isodensities $\left(\rho_{\mathrm{s}}=0.01 \mathrm{e} / \AA^{3}\right)$ were plotted together with selected Molecular Orbitals (MO).

Main axes of a diagonalized g-tensor were estimated in order to investigate the EPR spectrum and consequently the behavior of the unpaired electron for all studied $\mathrm{Cu}(\mathrm{II})$ complexes.

All the quantum chemical calculations were performed using Gaussian 03 program package[88]. NBO v. 5.0 program from Wisconsin University[89] was used to evaluate the Natural Bond Orbital (NBO) characteristics and AIMPAC program was used Bader's AIM[90] (Atoms in Molecules) analyses . For visualization of geometries, spin densities, and molecular orbitals, graphical programs Molden v. 4.4[91] and Molekel v. 4.3[92,93] were used.

\section{Results and Discussion}




\subsection{Structures}

Structures of both oxidized and reduced centers of the A and B Types (see Figure 2) of blue copper proteins were optimized in consequent steps with selected coordinates frozen in order to enlighten the role of the protein constraints.

\subsubsection{Protein structures - Constrained optimizations}

The averaged coordination distances for the oxidized $\mathrm{Cu}$ (II) centers of the both Types are compiled in Table 1. Bond lengths obtained from the constrained optimizations correspond directly to the PDB distances from the X-ray structures.

In average, the $\mathrm{Cu}(\mathrm{II})-\mathrm{S}($ cysteine) bonds are about $2.2 \AA$ long. For a comparison, the $\mathrm{Cu}-\mathrm{X}(\mathrm{S}, \mathrm{O}, \mathrm{N})$ distances (in $\AA$ ) for $\left[\mathrm{Cu}\left(\mathrm{H}_{2} \mathrm{~S}\right)_{\mathrm{m}}\left(\mathrm{H}_{2} \mathrm{O}\right)_{\mathrm{n}}\left(\mathrm{NH}_{3}\right)_{\mathrm{k}}\right]^{2+/+}$ cations from our previous study[79] are presented in Table 2 together with values obtained from the CSD database by Katz et al.[23]. Significantly longer $\mathrm{Cu}(\mathrm{II})-\mathrm{S}$ distances (about $2.4 \AA$ ) were found in the 4-coordinated complexes with electroneutral $\mathrm{H}_{2} \mathrm{~S}$ ligands. In the models of blue copper proteins, the shorter $\mathrm{Cu}-\mathrm{S}(\mathrm{Cys})$ bond can be explained by a stronger enhancement of the dative bond by electrostatic interaction between the $\mathrm{Cu}^{2+}$ cation and the present $\mathrm{Cys}$ model (thiolate $\left[\mathrm{S}\left(\mathrm{CH}_{3}\right)\right]^{1-}$ ). In the case of Met model (thioether group $\left.\mathrm{S}\left(\mathrm{CH}_{3}\right)_{2}\right)$, only a weaker monopole-dipole ( $\mu=1.6 \mathrm{D})$ interaction is present. This fact correlates with the visibly longer $\mathrm{Cu}-$ S(Met) bond (ca $2.89 \AA$ ). Glutamine exhibits coordination distances of about $2.15 \AA$. It is caused by smaller radii of the oxygen atom (in comparison with more diffuse sulfur) and by a larger dipole moment $(\mu=4.0$ D) of the acetyl-amine group. Corresponding bond lengths of the $\mathrm{Cu}(\mathrm{II})$ aqua complexes from our previous study[79] were determined to amount in average to $2.01 \AA$. The difference can be partially explained by the forced geometry of the protein centers, where the axial position of the $4^{\text {th }}$ ligand is disfavored (cf. below). 


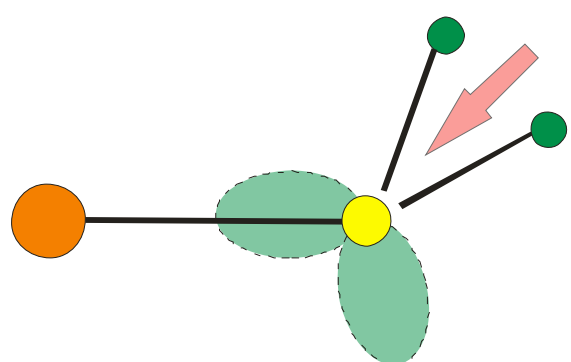

a)

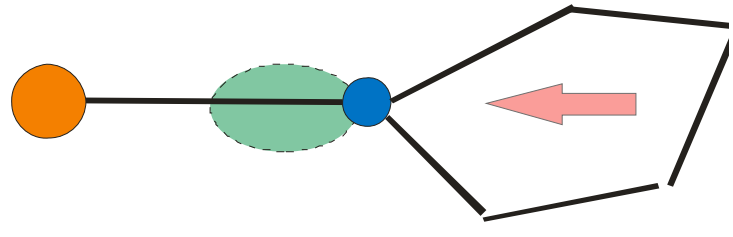

b)

Scheme 4: Metal-ligand arrangements for $\boldsymbol{a}$ ) methionine and $\boldsymbol{b}$ ) histidine molecules. Dashed ellipses represent lone pairs of ligands, while arrows stand for dipole orientations.

Orientation of the ligand is a result of a competition of electrostatic and dative interactions between metal and donating lone pairs of ligand molecules. According to Scheme $4 \boldsymbol{a}$, ligands with oxygen and sulfur atoms usually do not have dipole moment oriented in the direction of $\mathrm{Cu}-\mathrm{L}$ bond. On the contrary, histidine has a more pronounced dipole moment nearly collinear with direction of the donated electron lone pair (and $\mathrm{Cu}-\mathrm{N}$ bond). This is one of the reasons why the two $\mathrm{Cu}-\mathrm{N}$ (His) distances are relatively short, about 1.97 and $2.04 \AA$ long. These bond lengths are in good agreement with our previous results for the ammine complexes (cf. Table 2).

The frozen PDB Cu-L coordination distances and the $\mathrm{L}_{1}-\mathrm{Cu}-\mathrm{L}_{2}$ valence angles represent an influence of the protein structure. The X-ray crystal structures of blue copper proteins have a $\mathrm{S}(\mathrm{Cys})$ atom and two $\mathrm{N}(\mathrm{His})$ atoms arranged in a triangle with central metal atom placed about $0.5 \AA$ above this plane. The $4^{\text {th }}$ residue is located in axial position, which is further modified by the oxidation state of the redox center.

The $\mathrm{Cu}(\mathrm{I})$-ligand bond lengths of the reduced copper centers are presented in the second part of Table 1. The $\mathrm{Cu}(\mathrm{I})-\mathrm{L}(\mathrm{L}=\mathrm{S}, \mathrm{N})$ distances undergo only slight changes in the oxidation/reduction process of the centers. A certain elongation of $\mathrm{Cu}$ O coordination bond occurs in the reduced complexes with glutamine (2.28 $⿱$ A). It 
should be stressed that an asymmetrical arrangement of the two $\mathrm{Cu}-\mathrm{N}(\mathrm{His})$ distances is apparent in the PDB structures.

When oxidation state is altered, the redox centers of blue copper proteins exhibit small changes in the copper-ligand distances, meaning that qualitatively the same geometry is conserved. This can be considered to be a consequence of the protein "matrix". For the previously studied[79] 4-coordinated inorganic copper complexes, transition from the $\mathrm{Cu}(\mathrm{II})$ to $\mathrm{Cu}(\mathrm{I})$ states is connected with pronounced structural changes from square-planar to tetrahedral ligand arrangements. When such systems are allowed to be even more relaxed, they transform to 2-coordinated structures as illustrated in Figure 3. This fact is important especially for the electron transferring proteins. Small structural changes of the active centers - basically changes of the $\mathrm{Cu}-\mathrm{L}(\mathrm{Met} / \mathrm{Gln})$ distances - minimize the reorganization energy $\lambda$ within the redox process, and thus enable a rapid electron transfer.

\subsubsection{Fully optimized structures in vacuo}

When the models of reduced centers are optimized without any restrictions in vacuo, interesting changes can be noticed (see Figures $4 \boldsymbol{a}$ and $\mathbf{4 b}$ ). The $\mathrm{Cu}$ atom, which lies above $\mathrm{S}, \mathrm{N}, \mathrm{N}$-plane in non-optimized $\mathrm{Cu}(\mathrm{I})$ structures, moves so that it is situated within this plane. In the Type B center, two additional H-bonds are formed between the carbonyl group and histidines $(\mathrm{d}(\mathrm{O} . . \mathrm{H}(\mathrm{His}))=2.16$ and $2.41 \AA$ ). Substantially weaker hydrogen bonding $[\mathrm{d}(\mathrm{S}($ Met $) .. \mathrm{H}(\mathrm{His}))=2.96 \AA$ and $\mathrm{d}(\mathrm{S}(\mathrm{Cys}) . . \mathrm{H}(\mathrm{His}))=3.07$ $\AA$ ] is surmised in the Type A center, too.

Coordination distances of the fully optimized $\mathrm{Cu}(\mathrm{I})$ complexes are presented in Table 1. While the thiolate $\mathrm{Cu}-\mathrm{S}(\mathrm{Cys})$ bond remains practically unchanged, the thioether $\mathrm{Cu}-\mathrm{S}(\mathrm{Met})$ and carbonyl $\mathrm{Cu}-\mathrm{O}(\mathrm{Gln})$ bonds elongate to 4.4 and $3.7 \AA$, respectively. The difference between the $\mathrm{Cu}-\mathrm{N}(\mathrm{His} 1)$ and $\mathrm{Cu}-\mathrm{N}(\mathrm{His} 2)$ distances 
becomes more pronounced in the fully optimized $\mathrm{Cu}(\mathrm{I})$ complexes. Moreover in the case of the Type A center, the $\mathrm{S}-\mathrm{Cu}-\mathrm{N}$ angle between $\mathrm{Cu}-\mathrm{S}(\mathrm{Cys})$ and the shorter of $\mathrm{Cu}-\mathrm{N}(\mathrm{His})$ bonds opens from $131^{\circ}$ (in average) to $151^{\circ}$. These features (illustrated in Scheme 5a) lead to an assumption that reduced centers without protein constraints would have a tendency to lower the coordination number (cf. similar trend in bond energies bellow). This finding is in accord with our previous work, where the $\mathrm{Cu}(\mathrm{I}) / \mathrm{Cu}(\mathrm{II})$ cations in the hydrogen sulfide-aqua-ammine ligand fields were investigated. It was shown that the "small" $\mathrm{Cu}(\mathrm{I})$ complexes with $\mathrm{O}-$ and N-ligands favor 2-coordinated structures[78], while the complexes with S-ligands usually prefer 3-coordination[79].

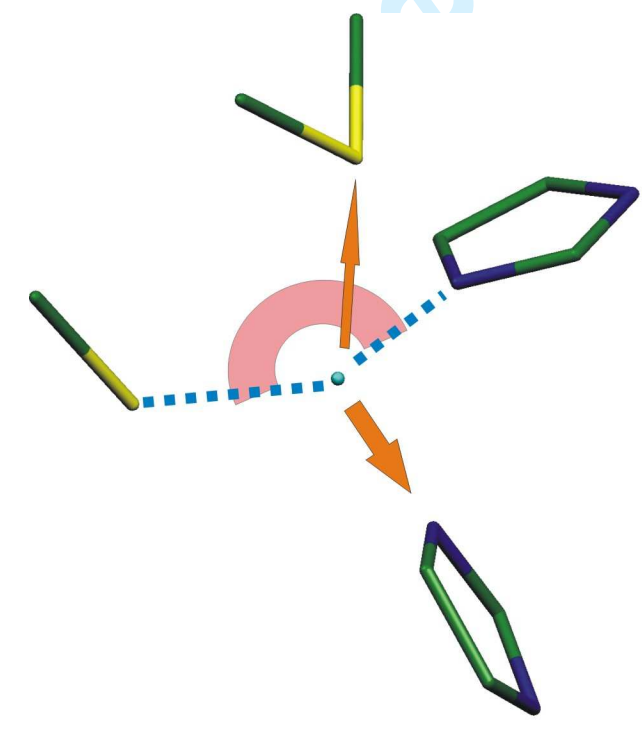

a)

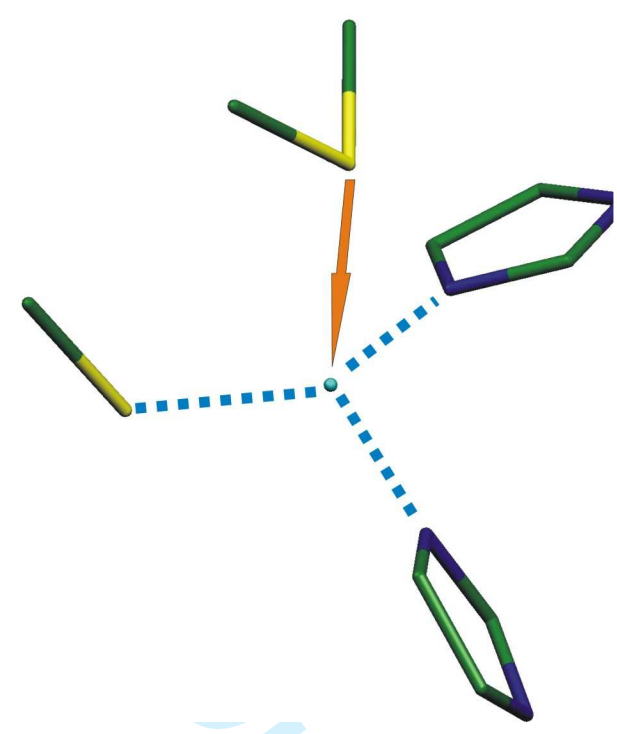

b)

Scheme 5: Type A centers: an illustration of changes when passing from PDB structures to fully optimized geometries in vacuo.
a) reduced $\mathrm{Cu}(\mathrm{I})$
b) oxidized $\mathrm{Cu}$ (II) centers.

The fully optimized models of the oxidized $\mathrm{Cu}(\mathrm{II})$ centers in vacuo revealed an opposite trend. The difference between two $\mathrm{Cu}(\mathrm{II})-\mathrm{N}(\mathrm{His})$ distances diminishes, especially for the Type A centers. Both the thioether $\mathrm{Cu}-\mathrm{S}$ and carbonyl $\mathrm{Cu}-\mathrm{O}$ bonds 
are visibly shortened. Therefore, formation of oxidized centers with 4-coordination geometry is favored; the same trend is confirmed from the bond energies below. The 4-coordination is also preferred for the inorganic $\left[\mathrm{Cu}\left(\mathrm{H}_{2} \mathrm{~S}\right)_{\mathrm{m}}\left(\mathrm{H}_{2} \mathrm{O}\right)_{\mathrm{n}}\left(\mathrm{NH}_{3}\right)_{\mathrm{k}}\right]^{2+}$ complexes[79].

The full optimization has marginal effect on the $\mathrm{Cu}-\mathrm{S}(\mathrm{Cys})$ distances in the case of the A centers. However in the B centers, the $\mathrm{Cu}-\mathrm{S}(\mathrm{Cys})$ bonds elongate. Such behavior can be considered to be a result of the ligand-donation competition between the carbonyl and thiolate groups. The donation effect from a more distant methionine was found negligible in the A centers. In the B centers, the full optimization leads to a substantially different coordination arrangement (see Figure $4 \boldsymbol{d}$ ). The relaxed complex possesses a geometry halfway between square planar and tetrahedral arrangements, which has some impact on electronic properties as will be demonstrated later.

A lot of studies was devoted to investigation of protein constraints on the active centers of blue copper proteins. An earlier paper[94] suggested that there are no constraints. However, such a proposal was later revised[33,34,45]. The role of axial ligand has also been widely studied[5,33,46,47,49,95,96]. The section above provides some answers to the questions about constraints imposed by the protein backbone structure:

a) Neither oxidized nor reduced centers have optimum geometries. The extent of these forces can be estimated from the stabilization energies (cf. Section 3.2.1).

b) When no constraint is applied, the axial copper-ligand bond elongates/shortens depending on reduced/oxidized state of metal, regardless the type of $4^{\text {th }}$ residue (Gln or Met). 
c) Changes in coordination in reduced centers correspond to the fact that the $\mathrm{Cu}(\mathrm{I})$ complexes prefer geometry with a lower-coordination. Analogously, models of the fully relaxed oxidized $\mathrm{Cu}($ II) centers tend to form four "equivalent" bonds as can be seen from unification of the $\mathrm{Cu}-\mathrm{N}$ (His) bonds and shortening of the $\mathrm{Cu}-\mathrm{L}$ distances of the $4^{\text {th }}$ ligand.

\subsubsection{Relaxed models in solvents}

The studied redox centers are influenced by their environment. Such effects were examined at the QM/MM level[32,43,97]. Polarized continuum models were also used for this kind of complexes in ref.[43]. Given the model used in our calculations, the subtler differences within the individual families of (both Type A and B) proteins cannot be reproduced. However, the influence of solvent effects can be still estimated in the PCM regime through the screening of electrostatic interactions. These effects can be important for more accurate energy analyses.

In case of the oxidized $\mathrm{Cu}(\mathrm{II})$ centers, solvation effects exhibit a lower influence on the fully optimized geometries than in the reduced $\mathrm{Cu}(\mathrm{I})$ complexes. Screened electrostatic interaction of the thiolate $\mathrm{Cu}-\mathrm{S}(\mathrm{Cys})$ bond results in a mild elongation with an increasing value of the dielectric constant. Since the donation effect is very distance-sensitive (it is linked to the overlap of $\mathrm{Cu}$ and $\mathrm{S} \mathrm{AOs}$ ), the cysteine donation weakens correspondingly. Simultaneously, shortening of the $\mathrm{Cu}$ $\mathrm{N}(\mathrm{His})$ bonds occurs increasing the donation competition. Interestingly, the distance of the $\mathrm{Cu}-\mathrm{O}(\mathrm{Gln})$ and $\mathrm{Cu}-\mathrm{S}(\mathrm{Met})$ bonds also shorten. Such a behavior causes a dative competition between the Cys and all other (neutral) ligands. In the Gln case, the strengthening of the $\mathrm{Cu}-\mathrm{O}(\mathrm{Gln})$ bond is in accord with the hard-soft-acid-base (HSAB) principle (oxygen is closer to the relatively hard $\mathrm{Cu}^{2+}$ cation than the sulfur atom[98]). 
For the solvated $\mathrm{Cu}(\mathrm{I})$ centers, the $\mathrm{Cu}-\mathrm{S}(\mathrm{Cys})$ distances elongate and similarly $\mathrm{Cu}-\mathrm{O}(\mathrm{Gln})$ reflecting the reduced electrostatic enhancement in (implicit) solvent.

\subsection{Energetics}

Energy analyses and determination of electron properties in next the section were performed at the B3LYP/6-311++G(2df,2pd) level.

\subsubsection{Stabilization energies}

Stabilization $\boldsymbol{\Delta} \boldsymbol{E}^{\text {Stab }}$ and total coordination $\boldsymbol{\Delta} \boldsymbol{E}^{\boldsymbol{T C} \boldsymbol{E}}$ energies are presented in Table 3. In the gas-phase calculations of the oxidized $\mathrm{Cu}$ (II) complexes, the stabilization energies of the B centers are about $6 \mathrm{kcal} / \mathrm{mol}$ higher than the $\Delta \boldsymbol{E}^{\text {Stab }}$ energies of the A centers under the constrained optimization. For the reduced $\mathrm{Cu}(\mathrm{I})$ centers, the $\mathrm{B}$ centers are still more stable but less than $1 \mathrm{kcal} / \mathrm{mol}$. When comparing the fully optimized structures, this difference remain similar in $\mathrm{Cu}(\mathrm{II})$ complexes but raises up to 9 $\mathrm{kcal} / \mathrm{mol}$ in reduced states.

The difference $\left[\boldsymbol{\Delta} \boldsymbol{E}^{\text {Stab }}\right.$ (full opt.) - $\boldsymbol{\Delta} \boldsymbol{E}^{\text {Stab }}$ (constrained opt.) $]$ estimates a relaxation energy of ligands. This relaxation amounts up to $21 \mathrm{kcal} / \mathrm{mol}$ in case of the reduced $\mathrm{B}$ centers in the gas phase and up to $12 \mathrm{kcal} / \mathrm{mol}$ in water. Comparing changes in $\boldsymbol{\Delta} \boldsymbol{E}^{S t a b}$ with $\boldsymbol{\Delta} \boldsymbol{E}^{\boldsymbol{T C E}}$ when passing from the constrained to fully optimized structures for all three environments, it can be noticed that while stabilization $\left(\Delta \boldsymbol{E}^{S t a b}\right)$ always increases there are several cases where the $\boldsymbol{A E}^{\boldsymbol{T C} \boldsymbol{E}}$ energy for the fully optimized structures is even lower than the corresponding value for the constrained structures. This indicates that besides changes in the $\mathrm{Cu}-\mathrm{L}$ coordinations, repulsion between the ligands is also minimized and some bonding interligand interactions can be formed. These interligand interactions can partially cause a decrease of particular 
$\mathrm{Cu}-\mathrm{L}$ bonding energy, which results in lower $\boldsymbol{\Delta} \boldsymbol{E}^{\boldsymbol{T C} \boldsymbol{E}}$ energy for fully optimized system.

Inclusion of the environment effects influences the stabilization energy as the screening decreases the electrostatic contribution to the bonding interaction between the $\mathrm{Cu}(\mathrm{I}) / \mathrm{Cu}(\mathrm{II})$ cation and ligands. Especially remarkable influence can be seen in the negatively charged model of cysteine. Therefore, the obtained $\Delta \boldsymbol{E}^{\text {Stab }}$ values are pronouncedly lowered when compared to in vacuo calculations. The dielectric constant, proportionally lowers the stabilization energies. An interesting behavior was found when relaxation of the protein constraints (estimated as a difference of the $\Delta \boldsymbol{E}^{\text {Stab }}$ energies of constrained and fully optimized structures) is considered. These values are drawn in Figure 5. This Figure illustrates several trends: a) In both types of the centers, the reduced $\mathrm{Cu}(\mathrm{I})$ complexes are less stable under protein constraints than the oxidized complexes. b) The B centers exhibit a higher energy relaxation after full optimization. c) The relaxation energies are most pronounced in the gas phase calculations, where stabilization increases after full optimization up to $21 \mathrm{kcal} / \mathrm{mol}$ (cf. Table 3 and Figure 5).

\subsubsection{Ligand bonding energies}

Bonding energies $\boldsymbol{\Delta} \boldsymbol{E}^{\boldsymbol{B} \boldsymbol{E}}$ of all the ligands in the studied redox centers are compiled in Table 4. Partitioning of the system into the ligand and the remaining part of the complex provides a useful insight into the strength of individual dative bonds. The $\mathrm{Cu}-\mathrm{S}(\mathrm{Cys})$ coordination clearly dominates in all investigated complexes with the $\Delta \boldsymbol{E}^{\boldsymbol{B} \boldsymbol{E}}$ energies in vacuo around 240 and $130 \mathrm{kcal} / \mathrm{mol}$ for the oxidized and reduced centers, respectively. Such high bonding energies are products of a dative coordination enhanced by a strong electrostatic interaction between the $\mathrm{Cu}^{2+/+}$ cation and cysteine model $\left[\mathrm{S}\left(\mathrm{CH}_{3}\right)\right]^{1-}$. For the $\mathrm{Cu}(\mathrm{II})$ complexes, $\boldsymbol{\Delta} \boldsymbol{E}^{\boldsymbol{B} \boldsymbol{E}}$ of the $\mathrm{Cu}-\mathrm{N}(\mathrm{His})$ 
bonds are by an order of magnitude weaker, ranging from $28 \mathrm{kcal} / \mathrm{mol}$ (in constrained opt.) to $36 \mathrm{kcal} / \mathrm{mol}$ (in full opt.). Coordination of the acetyl group in the $\mathrm{Cu}-\mathrm{O}(\mathrm{Gln})$ model was estimated to be about $11 \mathrm{kcal} / \mathrm{mol}$ for the restrained structure and about 20 $\mathrm{kcal} / \mathrm{mol}$ for the fully optimized complex. The weakest bonding energies are visible for the thioether $\mathrm{Cu}-\mathrm{Met}$ bonds, less than $13 \mathrm{kcal} / \mathrm{mol}$. The coordination energy for the $4^{\text {th }}$ residue reflects the shortening of these $\mathrm{Cu}-\mathrm{L}$ bonds described in the geometry discussion above. It confirms the tendency for 4-coordination of the $\mathrm{Cu}$ (II) structures when no protein constraints are applied.

In the reduced centers, the $\mathrm{Cu}-\mathrm{L}$ coordination bonds in protein imposed structures are noticeably weaker than in the $\mathrm{Cu}(\mathrm{II})$ case, mainly due to the reduction of electrostatic contributions. Actually, the $\boldsymbol{\Delta} \boldsymbol{E}^{\boldsymbol{B} \boldsymbol{E}}$ energies of the $\mathrm{Cu}-\mathrm{Met} / \mathrm{Gln}$ bonds exhibit negative values in our model. This can be explained by the fact that the $\boldsymbol{\Delta} \boldsymbol{E}^{\boldsymbol{B} \boldsymbol{E}}$ energies also contain an interligand repulsion, which can be stronger than weak $\mathrm{Cu}(\mathrm{I})$ $\mathrm{L}$ attractive interaction. For the fully optimized complexes in vacuo (without protein constraints) no negative bonding energies were obtained since the repulsive ligandligand interactions were minimized. In the geometry discussion, it was proposed that the reduced centers tend to lower coordination numbers. A partial support for this statement can be seen in differences of the $\boldsymbol{\Delta} \boldsymbol{E}^{\boldsymbol{B} \boldsymbol{E}}$ values for the $\mathrm{Cu}-\mathrm{His} 1$ and $\mathrm{Cu}-\mathrm{His} 2$ bonds in the fully optimized structures. Here, one can notice that only two $\boldsymbol{\Delta} \boldsymbol{E}^{\boldsymbol{B} \boldsymbol{E}}$ energies of the $\mathrm{Cu}(\mathrm{I})$ - $\mathrm{L}$ bonds are higher than $6 \mathrm{kcal} / \mathrm{mol}$ in the gas-phase calculations, which can be interpreted that only two $\mathrm{Cu}(\mathrm{I})$ - $\mathrm{L}$ dative bonds are present in the reduced A centers. Such an argument is not convincing for the B centers in accord with higher stability of the 3-coordinated $\left[\mathrm{Cu}\left(\mathrm{H}_{2} \mathrm{~S}\right)\left(\mathrm{H}_{2} \mathrm{O}\right)\left(\mathrm{NH}_{3}\right)_{2}\right]^{+}$complexes.

\subsubsection{Ionization potentials}


In order to describe transition between the $\mathrm{Cu}(\mathrm{II})$ and $\mathrm{Cu}(\mathrm{I})$ oxidation states, vertical $\boldsymbol{I P}^{\text {vert }}$ and adiabatic $\boldsymbol{I \boldsymbol { P } ^ { a d i a b }}$ ionization potentials were calculated according to the equation (2). The obtained values are listed in Table 5. It can be noticed that the IP values decrease rapidly with an increasing relative permittivity. In the constrained optimizations, lower values of both vertical and adiabatic IP for the B centers can be seen regardless of the type of the environment. Optimized structures in all three environments display an inverted order of $\boldsymbol{I P}(\boldsymbol{I P}$ (type $A)<\boldsymbol{I P}($ type $B))$ for vertical transitions and for the adiabatic $\boldsymbol{I P}^{\text {adiab }}$ energies in vacuo and protein-like neighborhood. It can be noticed that structural relaxation leads to increase of IP values as one could expect according to larger stabilization of reduced complexes from Figure 5. The more pronounced stabilization of reduced Type B centers (especially in gas phase and protein-like environment) is responsible for the inverted order of IP in these optimized (relaxed) complexes.

Experimentally obtained redox potentials $\boldsymbol{E}_{\boldsymbol{0}}$ for the studied proteins are presented in Table 6. There are also recent calculations on the T-1 blue-copperproteins reduction potential, which treats larger model and reproduce experimental results fairly accurately[99]. Although our calculations are not able to reveal $\boldsymbol{E}_{\boldsymbol{0}}$ values for individual proteins, it is at least partially possible to compare the relative differences between the $\mathrm{A}$ and $\mathrm{B}$ families. The difference of $0.14 \mathrm{eV}$ obtained from experiment is in good agreement with the difference $\boldsymbol{I P}^{\text {adiab }}$ (type A) - $\boldsymbol{I P}^{\text {adiab }}$ (type B) $(=0.19 \mathrm{eV})$ from the present work. There is relatively large variation of the redox potential of type A family (cf.Table 6) so one should take the comparison only as a qualitative insight.

\subsection{Electron structure}


Electron distributions of the redox centers of blue copper proteins were investigated in terms of the NPA partial charges, AIM and molecular orbital (MO) analysis, and spin densities together with the EPR spectra estimation.

\subsubsection{Charge and spin density distribution}

The electron spin densities in terms of partial atomic spin densities $\left(\boldsymbol{\rho}_{s}\right.$ obtained by the NPA method) are summarized in Table 7. Since there is a strong dative interaction between $\mathrm{Cu}^{2+}$ and cysteine model $\left.\left[\mathrm{S}_{\left(\mathrm{CH}_{3}\right)}\right)\right]^{-}$, most of the spin density $(80-90 \%)$ is located on the $\mathrm{Cu}-\mathrm{S}(\mathrm{Cys})$ bond as it can be observed in Figure 6. The B centers exhibit a higher portion of spin density $\rho_{s}$ on $\mathrm{Cu}$ and lower $\rho_{s}$ on the sulfur atom of the cysteine model when compared to the A centers. It shows that in oxidized Type B centers, always lower donation occurs from cysteine sulfur than in Type A centers, leaving larger spin density on copper cation. This is linked with a stronger donation ability of the Gln residue (than Met). These analyses are in good accord with other computational works - similar picture was already obtained in study of De Kerpel et al.[100].

Partial atomic charges $\delta$ obtained by the NPA are compiled in Table 8 for the copper cation and all the donating atoms. For both $\mathrm{Cu}(\mathrm{I})$ and $\mathrm{Cu}(\mathrm{II})$ complexes, atomic charges closely reflect the donation from the individual ligands. The partial charges give an insight on how much of electron density from the given atom is approximately involved in the (dative) bonding (cf. Tables 8 ). It can be noticed that Type B centers exhibit in oxidized state lower donation from cysteine - in accord with spin densities (and AIM analysis) but (generally) slightly larger donation occurs in case of histidine ligands, which is also supported by larger electron densities in $\mathrm{Cu}-\mathrm{N}$ critical points in AIM analysis. In the case of Cysteine $(\boldsymbol{\delta}(\mathrm{S})=-0.74$ e for isolated $\left[\mathrm{S}\left(\mathrm{CH}_{3}\right)\right]^{-}$in vacuo), the partial charge is reduced (in absolute value) to $-0.57 \mathrm{e}$ in 
structure of $\mathrm{Cu}(\mathrm{I})$ centers. It shows that polarization by the $\mathrm{Cu}$ cation causes shifting of the electron density towards the cation in all the ligands. Part of this electron density is then used for metal donation. In case of the $\mathrm{Cu}$ (II) complexes, the effect is even more pronounced resulting in the reduction of partial charge of sulfur atom as low as -0.13 e. This situation can be recognized as a transfer of almost the whole electron from Cys to $\mathrm{Cu}(\mathrm{II})$. The same description follows from the discussion of the electron spin densities (see above). In the Met residue, positive $\delta(S)$ values were found on the $S$ atom in all cases. In the reduced centers, the sulfur partial charges do not change substantially compared to an isolated molecule, since the $\mathrm{Cu}(\mathrm{I})-\mathrm{S}(\mathrm{Met})$ distances are very long. In the $\mathrm{Cu}(\mathrm{II})$ complexes, the partial charges in vacuo are lowered by about 0.04 e compared to the isolated $\mathrm{S}\left(\mathrm{CH}_{3}\right)_{2}$ molecule reflecting some shortening of the $\mathrm{Cu}-\mathrm{S}(\mathrm{Met})$ bond in oxidized centers as well as their positive $\boldsymbol{\Delta} \boldsymbol{E}^{\boldsymbol{B} \boldsymbol{E}}$ bond energies. Results for the thioether ligand can be also compared with our previous study[79], where the $\left[\mathrm{Cu}\left(\mathrm{H}_{2} \mathrm{~S}\right)_{n}\right]^{2+/+}$ complexes $(\mathrm{n}=1-4)$ with neutral hydrogen sulfide displayed $\delta(\mathrm{S})=-0.1$ and -0.2 e for the $\mathrm{Cu}(\mathrm{II})$ and $\mathrm{Cu}(\mathrm{I})$ systems, respectively. These more negative values (in contrary to Met) are product of a much shorter coordination distances in these inorganic complexes.

Partial charge on the $\mathrm{Cu}$ atom was estimated to be about 0.96 and 0.69 e for the oxidized and reduced $\mathrm{A}$ centers in vacuo, respectively. For the $\mathrm{Cu}(\mathrm{II}) / \mathrm{Cu}(\mathrm{I})$ cations in the B centers, slightly higher values $\delta=1.04 / 0.74$ e were obtained. The difference can be explained by a weaker $\mathrm{Cu}-\mathrm{Cys}$ donation in the $\mathrm{B}$ complexes, which represents the main contribution to the partial charge reduction of the copper cations. When solvation effects are considered, the $\mathrm{Cu}$ partial charge increases with a decreasing dative interaction of the ligands as a consequence of a bond elongation. It is a result of the more effective screening of electrostatic interactions, which enhances 
the dative bonds especially in the case of negatively charged model of the Cysteine side chain.

\subsubsection{Molecular orbitals analysis}

In this part, only behavior of single occupied molecular orbitals (SOMO) in the oxidized centers will be discussed. The analysis revealed three types of SOMO, which are illustrated in Figure 7. The first type (7a) represents a typical SOMO occurring in the A centers, which was also presented in some other works[45,47,49]. In this type, the $3 p_{\pi}$ orbital of $\mathrm{S}(\mathrm{Cys})$ is combined with $3 d_{x^{2}-y^{2}}$ AO of copper. The second type (7b) contains nonbonding admixture of $\mathrm{S}(\mathrm{Cys}) 3 \mathrm{p}_{z}$ orbital perpendicular to the $3 d_{x^{2}-y^{2}}$ $\mathrm{AO}$ of $\mathrm{Cu}$. The fully optimized $\mathrm{A}$ centers and the protein structures of $\mathrm{B}$ centers possess this type of SOMO. In the third type of molecular orbital (7c), SOMO is dominantly composed of copper $3 \mathrm{~d}$ AO's so that the lobes aim to all four $\mathrm{Cu}$-ligand bonds.

\subsubsection{EPR spectrum of oxidized centers}

EPR spectra represent an important tool for investigation of the $\mathrm{Cu}$ (II) complexes, since the method is based on magnetic properties of the unpaired electrons. The key tensor property called the g-factor describes how a local magnetic field is induced by the external magnetic field. It approaches the value of 2.0023 for a single free electron. Similar values should be obtained for systems with delocalized unpaired electron. Otherwise, it can markedly rise. Main axes of the diagonalized g-tensor were determined for all the studied $\mathrm{Cu}(\mathrm{II})$ complexes (Table 9). Experimental values are listed as well. In case of the protein imposed structures, $\mathrm{g}_{\|}$and $\mathrm{g}_{\perp}$ values in vacuo were estimated to be about 2.12 and 2.05 a.u., respectively. This anisotropic splitting of the g-factor is close to the experimental values (2.23 and 2.05) for the A centers of 
the blue copper proteins[13,96]. Considering the solvent effects in the COSMO regime slightly improves the calculated $\mathrm{g}_{\|}$values. However, in order to obtain a better agreement with the experiment, the hybrid functional needs to be modified by fitting the ratio of the DFT exchange-correlation and the Hartree-Fock exchange terms as discussed e.g. in review[13]. On the other hand, the B3LYP functional successfully reproduces higher $\mathrm{g}_{\|}$values for the B centers, even in vacuo. The fully optimized A complex exhibits similar behavior as the protein structures from the database. In case of the B center, full optimization reveals a different trend, where $g_{\|}$is very similar to $\mathrm{g}_{\perp}=2.08$. Such behavior can be explained by pronounced geometry changes in the fully optimized B center with a more competitive Gln ligand as mentioned in the previous geometry discussion and demonstrated in Figure $4 \boldsymbol{d}$. In this way, extensive redistribution of unpaired electron occurs as it was already illustrated by plots of spin densities in Figure 6.

For the solvated complexes, the distinction between $g_{\|}$and $g_{\perp}$ increases with dielectric constant in the $\mathrm{A}$ centers as a reaction to the shortening of $\mathrm{Cu}-\mathrm{N}$ bonds and concentrating electron density in N,N,S plane. On the contrary, the difference between both g components decreases in the $\mathrm{B}$ centers since a simultaneous increase of the $\mathrm{Cu}$ $\mathrm{S}(\mathrm{Cys})$ and decrease of $\mathrm{Cu}-\mathrm{O}(\mathrm{Gln})$ distances causes formation of a more symmetrical (isotropic) arrangement (cf. Table 1).

\section{Conclusions}

Models of mononuclear centers of blue copper proteins were investigated in the present study. Two families of these proteins were examined: the Type A centers with methionine side chain as the fourth residue and the Type B centers with glutamine residue. 
Selected structures were optimized at the B3LYP/6-31+G(d) level. Starting geometries of the complexes were taken from the PDB database (active centers from seven proteins - Type A: amicyanin, auracyanin, plastocyanin, rusticyanin; Type B: mavicyanin, stellacyanin, and umecyanin). Both reduced and oxidized states were investigated in the gas phase as well as in the implicit solvent regime (in COSMO approach) simulating water $(\varepsilon=78)$ and protein-like environment $(\varepsilon=4)$. First, in the constrained optimizations stage, the structural restrictions related to the presence of the protein matrix were partially taken into account. In the final step, all these constraints were released. Differences between both optimizations revealed that neither oxidized nor reduced structures of the copper centers stay in their optimum geometries. In comparison with the PDB structures, the axial $\mathrm{Cu}-\mathrm{L}$ bond elongates/shortens depending on the reduced/oxidized state of the central metal, regardless the type of protein (A or B). In reduced centers, relaxation of coordination bonds corresponds to fact that the $\mathrm{Cu}(\mathrm{I})$ complexes prefer geometry with a lower coordination. Analogously, models of the fully relaxed oxidized $\mathrm{Cu}$ (II) centers tend to form four "equivalent" bonds.

Detailed insight into the properties of these $\mathrm{Cu}(\mathrm{I}) / \mathrm{Cu}(\mathrm{II})$ complexes is provided by energy analyses performed at the more accurate B3LYP/6$31++G(2 d f, 2 p d)$ level. According to differences in the stabilization energies with and without constraints, oxidized states of the both A and B centers are in average closer to the optimized geometries (as follows from the lower relaxation energies drawn in Figure 5). Higher relaxation energy is released within the full optimization for the Type B centers.

Ionization potentials were used for characterization of the transitions between the $\mathrm{Cu}(\mathrm{II}) / \mathrm{Cu}(\mathrm{I})$ redox states. For constrained structures, $\boldsymbol{I P}($ type $\mathrm{A})>\boldsymbol{I P}($ type $\mathrm{B})$ 
trend was obtained regardless of the type of environment. In the case of fully optimized structures, the order is altered for vertical transitions in all three types of surroundings as well as for adiabatic transition in vacuo and protein like environment. Nevertheless, higher $\boldsymbol{I} \boldsymbol{P}^{\text {adiab }}$ values were found for the A centers optimized within the COSMO approach for water. Such behavior reflects the ability of the solvent to influence the redox properties of the studied centers. Comparing relative difference between the constrained $\mathrm{A}$ and $\mathrm{B}$ proteins centers, the redox potential difference $\boldsymbol{\Delta} \boldsymbol{E}_{\boldsymbol{0}}$ $=0.20 \mathrm{eV}$ was obtained, which is in accord with experimentally known data (of about $0.14 \mathrm{eV})$. But as already stated, this conclusion should be take with care due to large fluctuation in redox potential of the Type A proteines.

Charge and spin distributions were obtained by the NPA method. They revealed that most of the spin density (80-90\%) is located on the $\mathrm{Cu}-\mathrm{S}(\mathrm{Cys})$ bond, which corresponds to a strong (enhanced) dative interaction between the copper cation and cysteine. The $\mathrm{B}$ centers exhibit a higher portion of spin density on $\mathrm{Cu}$ as well as a higher partial charge localized on the $\mathrm{Cu}$ atom compared to the A centers. Such behavior reflects the stronger ability of the Gln ligand to donate electron density compared to the Met ligand.

For the $\mathrm{Cu}$ (II) complexes, characteristics of the EPR spectra (g-factors) were also estimated. Despite some differences occurred comparing calculated and experimental values of the $g_{\|}$component, in general the anisotropy trend of the electron spin density was determined correctly. This can be also demonstrated on the maps of spin densities in Figure 6. Interesting behavior was found for the fully optimized B center, for which a distinct EPR spectrum and character of SOMO orbital were found. This feature can be explained by a markedly different, (near-tetrahedral, i.e. more symmetrical) geometry of this complex. 


\section{Acknowledgement}

This study was supported by MSM 0021620835 grants. We are grateful for the access to the excellent computational resources of the Charles University Meta-Centrum in Prague. A special thank must be given to the KFCHO department computer cluster administrator Dr. Šimánek. 


\section{References:}

[1] J.A. Cowan: Inorganic Biochemistry: An Introduction. , VCH Publishers, New York, 1993.

[2] ProMiS: Prosthetic groups and Metal Ions in Protein Active Sites http://metallo.scripps.edu/PROMISE/CUMAIN.html (1998).

[3] E.I. Solomon: Spectroscopic Methods in Bioinorganic Chemistry: Blue to Green to Red Copper Sites. Inorg. Chem. 458012 (2006).

[4] X. Wang, S.M. Berry, Y. Xia, Y. Lu: The Role of Histidine Ligands in the Structure of Purple Cua Azurin. J. Am. Chem. Soc. 1217449 (1999).

[5] A.E. Palmer, D.W. Randall, F. Xu, E.I. Solomon: Spectroscopic Studies and Electronic Structure Description of the High Potential Type 1 Copper Site in Fungal Laccase: Insight into Effect of the Axial Ligand. J Am. Chem. Soc. 1217138 (1999).

[6] S. Santra, P. Zhang, W. Tan: Novel Interaction between Glutamate and the Cu2+/DMABN/beta-CD Complex. J. Phys. Chem. A 10412021 (2000).

[7] K. Shimizu, H. Maeshima, H. Yoshida, A. Satsuma, T. Hattori: Ligand field effect on the chemical shift in XANES spectra of $\mathrm{Cu}$ (II) compounds. Phys. Chem. Chem. Phys. 3862 (2001).

[8] M.L. Barrett, I. Harvey, M. Sundararajan, R. Surendran, J.F. Hall, M.J. Ellis, M.A. Hough, R.W. Strange, I.H. Hillier, S.S. Hasnain: Atomic Resolution Crystal Structures, EXAFS, and Quantum Chemical Studies of Rusticyanin and Its Two Mutants Provide Insight into Its Unusual Properties. Biochem. 45 2927 (2006).

[9] P. Manikandan, B. Epel, D. Goldfarb: Structure of Copper(II)-Histidine Based Complexes in Frozen Aqueous Solutions As Determined from High-Field Pulsed Electron Nuclear Double Resonance. Inorg. Chem. 40781 (2001).

[10] J.A. Sigman, B.C. Kwok, A. Gengenbach, Y. Lu: Design and Creation of $\mathrm{Cu}(\mathrm{II})$-Binding Site in Cytochrome c Peroxidase that Mimics the Cub-heme Center in Terminal Oxidases. J Am. Chem. Soc. 1218949 (1999).

[11] H.B. Gray, B.G. Malmstroem, R.J.P. Williams: Copper coordination in blue proteins. J. Biol. Inorg. Chem. 5551 (2000).

[12] E.I. Solomon, M.J. Baldwin, M.D. Lowery: Electronic Structures of Active Sites in Copper Proteins: Contribution to Reactivity. Chem. Rev. 92521 (1992).

[13] E.I. Solomon, R.K. Szilagyi, S.D. George, L. Basumallick: Electronic Structures of Metal Sites in Proteins and Models: Contribution to Function in Blue Copper Proteins. Chem. Rev. 104419 (2004).

[14] L.M. Mirica, X. Ottenwaelder, T.D.P. Stack: Structure and Spectroscopy of Copper-Dioxygen Complexes. Chem. Rev. 1041013 (2004).

[15] L.D. Book, D.C. Arnett, H. Hu, N.F. Scherer: Ultrafast Pump-Probe Studies of Excited-State Charge Transfer Dynamics in Blue Copper Proteins. J. Phys. Chem. A 1024350 (1998).

[16] E. Fraga, M.A. Webb, G.R. Loppnow: Charge-Transfer Dynamics in Plastocyanin, a Blue Copper Protein, from Resonance Raman Intensities. J. Phys. Chem. 1003278 (1996).

[17] A.W. Holland, R.G. Bergman: Heterocumulene Metathesis by Iridium Guanidinate and Ureylene Complexes: Catalysis Involving Reversible Insertion To Form Six-Membered Metallacycles. J. Am. Chem. Soc. 124 9010 (2002). 
[18] P.L. Holland, W.B. Tolman: Three-Coordinate Cu(II) Complexes: Structural Models of Trigonal-Planar Type 1 Copper Protein Active Sites. J Am Chem. Soc. 1217270 (1999).

[19] M.K. Taylor, D.E. Stevenson, L.E.A. Berlouis, A.R. Kennedy, J. Reglinski: Modelling the impact of geometric parameters on the redox potential of blue copper proteins. J. Innorg. Biochem. 100250 (2005).

[20] D.F. Raffa, R. Gomez-Balderas, P. Brunelle, G.A. Rickard, A. Rauk: Ab initio model studies of copper binding to peptides containing a His-His sequence: relevance to the beta-amyloid peptide of Alzheimer's disease. $\mathrm{J}$ Biological Inorg. Chem. 10887 (2005).

[21] J. Sabolovic, K.R. Liedl: Why are $\mathrm{Cu}(\mathrm{II})$ amino acid complexes not planar in their crystal structures? An ab initio and molecular mechanics study. Inorg. Chem. 382764 (1999).

[22] J. Sabolovic, C.S. Tautermann, T. Loerting, K.R. Liedl: Modeling anhydrous and aqua copper(II) amino acid complexes: A new molecular mechanics force field parametrization based on quantum chemical studies and experimental crystal data. Inorg. Chem. 422268 (2003).

[23] A. Katz, L. Shimoni-Livny, O. Navon, N. Navon, C. Bock, J. Glusker: Copper-binding motifs: Structural and theoretical aspects. HELVETICA CHIMICA ACTA (2003).

[24] L. Rulíšek: Theoretical studies of the interactions of transition metals with biomolecules. Chemicke Listy 96132 (2002).

[25] L. Rulíšek, Z. Havlas: Theoretical Studies of Metal Ion Selectivity. 1. DFT Calculations of Interaction Energies of Amino Acid Side Chains with Selected Transition Metal Ions (Co2+, Ni2+, $\mathrm{Cu} 2+, \mathrm{Zn} 2+, \mathrm{Cd} 2+$, and $\mathrm{Hg} 2+)$. J. Am. Chem. Soc. 12210428 (2000).

[26] L. Rulíšek, Z. Havlas: Theoretical Studies of Metal Ion Selectivity. 3. A Theoretical Design of the Most Specific Metal-Binding Sites of Metalloproteins for Selected Transition Metal Ions $(\mathrm{Co} 2+, \mathrm{Ni2}+, \mathrm{Cu} 2+, \mathrm{Zn} 2+$, Cd2+, and Hg2+). J. Phys. Chem. B 1072376 (2003).

[27] J. Bertran, L. Rodrigues-Santiago, M. Sodupe: The Different Nature of Bonding in $\mathrm{Cu}+-$ Glycine and Cu2+ -Glycine. J. Phys. Chem. B 1032310 (1999).

[28] T. Shoeib, H.E. Aribi, K.W.M. Siu, A.C. Hopkinson: A Study of Silver (I) Ion-Organonitrile Complexes: Ion Structures, Binding Energies, and Substituent Effects. J. Phys. Chem. A 105710 (2001).

[29] D. Caraiman, T. Shoeib, K. Siu, A. Hopkinson, D. Bohme: Investigations of the gas-phase reactivity of $\mathrm{Cu}+$ and $\mathrm{Ag}+$ glycine complexes towards $\mathrm{CO}, \mathrm{D} 2 \mathrm{O}$ and NH3. Int. J. Mass Spectrom. 228629 (2003).

[30] M. Breza, S. Biskupic: On the reduced form of (imidazole-N-3)(Nsalicylidene-alaninato-O,N,O ') copper(II). J Molecular Structure-Theochem 770139 (2006).

[31] T. Shuku, K. Sugimori, A. Sugiyama, H. Nagao, T. Sakurai, K. Nishikawa: Molecular orbital analysis of active site of oxidized azurin: Dependency of electronic properties on molecular structure. Polyhedron 242665 (2005).

[32] M.H.M. Olsson, G.Y. Hong, A. Warshel: Frozen density functional free energy simulations of redox proteins: Computational studies of the reduction potential of plastocyanin and rusticyanin. J Am. Chem. Soc. 1255025 (2003). 
[33] M.H.M. Olsson, U. Ryde: The influence of axial ligands on the reduction potential of blue copper proteins. J. Biol. Inorg. Chem. 4654 (1999).

[34] M.H.M. Olsson, U. Ryde, B.O. Roos, K. Pierloot: On the relative stability of tetragonal and trigonal $\mathrm{Cu}$ (II) complexes with relevance to the blue copper proteins. J. Biol. Inorg. Chem. 3109 (1998).

[35] S. Corni, F. De Rienzo, R. Di Felice, E. Molinari: Role of the electronic properties of azurin active site in the electron-transfer process. International $\mathbf{J}$ Quantum Chem. 102328 (2005).

[36] A. Warshel: Computer Modeling of Chemical Reactions in Enzymes and Solutions, John Wiley \& Sons, Ltd., New York, 1991.

[37] R. Prabhakar, P.E.M. Siegbahn: Theoretical study of the mechanism for the oxidative half-reaction of copper amine oxidase (CAO). J Physical Chem. B 1073944 (2003).

[38] K. Yoshizawa, Y. Shiota: Conversion of methane to methanol at the mononuclear and dinuclear copper sites of particulate methane monooxygenase (pMMO): A DFT and QM/MM study. J Am. Chem. Soc. 1289873 (2006).

[39] M. van den Bosch, M. Swart, J.G. Snijders, H.J.C. Berendsen, A.E. Mark, C. Oostenbrink, W.F. van Gunsteren, G.W. Canters: Calculation of the redox potential of the protein azurin and some mutants. Chembiochem 6738 (2005).

[40] Siegbahn, in I. Prigogine, S.A. Rice (Eds.), Advances in Chem. Physics, Volume XCIII. John Wilet \& Sons, Ltd., 1996, p. 333.

[41] K.W. Penfield, A.A. Gewirth, E.I. Solomon: J. Am. Chem. Soc. 1074519 (1985).

[42] A.A. Gewirth, E.I. Solomon: J. Am. Chem. Soc. 1103811 (1988).

[43] S. Sinnecker, F. Neese: QM/MM calculations with DFT for taking into account protein effects on the EPR and optical spectra of metalloproteins. Plastocyanin as a case study. J Computational Chem. 271463 (2006).

[44] L.B. LaCroix, S.E. Shadle, Y.N. Wang, e. al: Electronic structure of the perturbed blue copper site in nitrite reductase: Spectroscopic properties, bonding, and implications for the entatic/rack state. J. Am. Chem. Soc. 118 7755 (1996).

[45] K. Pierloot, J.O.A. De Kerpel, U. Ryde, B.O. Roos: J. Am. Chem. Soc. 119 218 (1997).

[46] D.W. Randall, S.D. George, B. Hedman, K.O. Hodgson, K. Fujisawa, E.I. Solomon: Spectroscopic and Electronic Structural Studies of Blue Copper Model Complexes. 1. Perturbation of the Thiolate-Cu Bond. J. Am. Chem. Soc. 12211620 (2000).

[47] L.B. LaCroix, D.W. Randall, A.M. Nersissian, e. al: Spectroscopic and geometric variations in perturbed blue copper centers: Electronic structures of stellacyanin and cucumber basic protein J. Am. Chem. Soc. 120 (1998).

[48] D.W. Randall, D.R. Gamelin, L.B. LaCroix, E.I. Solomon: Electronic structure contributions to electron transfer in blue $\mathrm{Cu}$ and Cua. J. Biol. Inorg. Chem. 515 (2000).

[49] J.A. Guckert, M.D. Lowery, E.I. Solomon: ELECTRONIC-STRUCTURE OF THE REDUCED BLUE COPPER ACTIVE-SITE - CONTRIBUTIONS TO REDUCTION POTENTIALS AND GEOMETRY. J. Am. Chem. Soc. 117 2817 (1995).

[50] K.J. de Almeida, R. Z., H.W. Hugosson, A.C. Ferreira, H. Agren: Modeling of EPR parameters of copper(II) aqua complexes Chem. Phys. 332176 (2007). 
[51] C. Remenyi, R. Reviakine, M. Kaupp: Density Functional Study of EPR Parameters and Spin-Density Distribution of Azurin and Other Blue Copper Proteins. J. Phys. Chem. B 1118290 (2007).

[52] K. Ando: Excited State Potentials and Ligand Force Field of a Blue Copper Protein Plastocyanin

J. Phys. Chem. B 1083940 (2004).

[53] K. Ando: Ligand-to-Metal Charge-Transfer Dynamics in a Blue Copper Protein Plastocyanin: A

Molecular Dynamics Study. J. Phys. Chem. B 112250 (2008).

[54] P. Comba, R. Remenyi: A New Molecular Mechanics Force Field for the Oxidized Form of Blue Copper Proteins. J. Comput. Chem. 23697 (2002).

[55] P. Comba, A. Lledo's, F. Maseras, R. Remenyi: Hybrid quantum mechanics/molecular mechanics studies of the active site of the blue copper proteins amicyanin and rusticyanin. Inorg. Chim. Acta 32421 (2001).

[56] P. Frank, M. Benfatto, R.K. Szilagyi, P. D'Angelo, S. Della Longa, K.O. Hodgson: The solution structure of $[\mathrm{Cu}(\mathrm{aq})](2+)$ and its implications for rackinduced bonding in blue copper protein active. Inorg. Chem. 441922 (2005).

[57] M. Konopka, R. Rousseau, I. Stich, D. Marx: Detaching thiolates from copper and gold clusters: Which bonds to break? J. Am. Chem. Soc. 12612103 (2004).

[58] H. Tachikawa: Ab initio MRSDCI calculations of the g-tensor components of $[\mathrm{Cu}(\mathrm{H} 2 \mathrm{O}) 6] 2+$ complexes. Chem. Phys.Lett. 260582 (1996).

[59] I.P. Hamilton: Complexes of cationic coinage metal clusters $\mathrm{M}-\mathrm{n}(+)(\mathrm{M}=\mathrm{Cu}$, $\mathrm{Ag}, \mathrm{Au} ; \mathrm{n}=1-4)$ and H2S: a theoretical study. Chem. Phys. Lett. 390517 (2004).

[60] G.W. Marini, K.R. Liedl, B.M. Rode: Investigation of Cu2+ Hydration and the Jahn-Teller Effect in Solution by QM/MM MC Simulations. J. Phys. Chem. A 10311387 (1999).

[61] C. Schwenk, B. Rode: Cu-II in liquid ammonia: An approach by hybrid quantum-mechanical/molecular-mechanical molecular dynamics simulation. CHEMPHYSCHEM 5 (3) (2004).

[62] C. Schwenk, B. Rode: Influence of heteroligands on structural and dynamical properties of hydrated $\mathrm{Cu} 2+$ : QM/MM MD simulations. PHYSICAL CHEMISTRY CHEMICAL PHYSICS 5 (16) (2003).

[63] H. Pranowo: Monte Carlo simulation of $\mathrm{CuCl} 2$ in $18.6 \%$ aqueous ammonia solution. CHEMICAL PHYSICS 291 (2) (2003).

[64] H.D. Pranowo, B.M. Rode: Solvation of $\mathrm{Cu} 2+$ in Liquid Ammonia: Monte Carlo Simulation Including Three-Body Corrections. J. Phys. Chem. A 103 4298 (1999).

[65] H.D. Pranowo, A.H.B. Setiajin, B.M. Rode: $\mathrm{Cu}+$ in Liquid Ammonia and in Water: Intermolecular Potential Function and Monte Carlo Simulation. J. Phys. Chem. A 10311115 (1999).

[66] D. Feller, E.D. Glendening, W.A. de Jong: Structures and binding enthalpies of $\mathrm{M}+(\mathrm{H} 2 \mathrm{O}) \mathrm{n}$ clusters, $\mathrm{M}=\mathrm{Cu}, \mathrm{Ag}, \mathrm{Au}$. J. Chem. Phys. 1101475 (1999).

[67] D. Schroeder, H. Schwartz, J. Wu, C. Wesdemiotis: Long-lived dications of $\mathrm{Cu}(\mathrm{H} 2 \mathrm{O}) 2+$ and $\mathrm{Cu}(\mathrm{NH} 3) 2+$ do exist! Chem. Phys. Lett. 343258 (2001).

[68] H.D. Pranowo, B.M. Rode: Prefential $\mathrm{Cu} 2+$ solvation in aqueous ammonia solution of various concetrations. Chem. Phys 2631 (2001). 
[69] F. Haeffner, T. Brinck, M. Haeberlein, C. Moberg: Force field parametrization of copper(I)-olefin systems from density functional calculations. Chem. Phys. Letters 39739 (1997).

[70] N.M.D.S. Cordeiro, J.A.N.F. Gomes: Ab Initio Copper-Water Interaction Potential for the Simulation of Aqueous Solutions. J. Comput. Chem. 14629 (1993).

[71] V. Subramanian, C. Shankaranarayanan, B.U. Nair, M. Kanthimathi, R. Manickkavachagam, T. Ramasami: Development of force field for some copper(II) Schiff-base complexes. Chem. Phys. Lett. 274275 (1997).

[72] N. Gresh, C. Policar, C. Giessner-Prettre: Modeling Copper(I) Complexes: SIBFA Molecular Mechanics versus ab Inition Energetics and Geometrical Arrangements. J. Phys. Chem. 1065660 (2002).

[73] M. Ledecq, F. Lebon, F. Durant, C. Giessner-Prettre, A. Marquez, N. Gresh: Modeling of copper(II) complexes with the SIBFA polarizable molecular mechanics procedure. Application to a new class of HIV-1 protease inhibitors. JOURNAL PHYSICAL CHEMISTRY B 107 (38) (2003).

[74] P. Schwerdtfeger, R.P. Krawczyk, A. Hammerl, R. Brown: A comparison of structure and stability between the group 11 halide tetramers M4X4 $(\mathrm{M}=\mathrm{Cu}$, $\mathrm{Ag}$, or $\mathrm{Au} ; \mathrm{X}=\mathrm{F}, \mathrm{Cl}, \mathrm{Br}$, or $\mathrm{I}$ ) and the group 11 chloride and bromide phosphanes (XMPH3)(4). Inorg. Chem. 436707 (2004).

[75] A. Berces, T. Nukada, P. Margl, T. Ziegler: Solvation of Cu2+ in Water and Ammonia. Insight from Static and Dynamical Density Functional Theory. J. Phys. Chem. A 1039693 (1999).

[76] F. Neese: Sum-over-states based multireference ab initio calculation of EPR spin Hamiltonian parameters for transition metal complexes. A case study. Magn. Res. Chem. 42 S187 (2004).

[77] J.V. Burda, M. Pavelka, M. Śimánek: Theoretical model of copper $\mathrm{Cu}(\mathrm{I}) / \mathrm{Cu}(\mathrm{II})$ hydration. DFT and ab initio quantum chemical study. J. Molec. Struct. THEOCHEM 683183 (2004).

[78] M. Pavelka, J.V. Burda: Theoretical model of copper $\mathrm{Cu}(\mathrm{I}) / \mathrm{Cu}(\mathrm{II})$ mixed aqua-amine complexes. DFT and ab initio quantum chemical study. Chem. Phys. 312193 (2005).

[79] M. Pavelka, M. Šimánek, J. Šponer, J.V. Burda: Copper Cation Interactions with Biologically Essential Types of Ligands: A Computational DFT Study. J. Phys. Chem. A 1104795 (2006).

[80] H.M. Berman, J. Westbrook, Z. Feng, G. Gilliland, T.N. Bhat, H. Weissig, I.N. Shindyalov, P.E. Bourne: The Protein Data Bank. Nucleic Acids Research 28235 (2000).

[81] M.M. Hurley, L.F. Pacios, P.A. Christiansen, R.B. Ross, W.C. Ermler: Ab Initio Relativistic Effective Potentials with Spin-Orbit Operators. II. K through Kr. J. Chem. Phys. 846840 (1986).

[82] A. Klamt: J. Phys. Chem. 992224 (1995).

[83] A. Klamt, G. Schuurmann: Cosmo - a New Approach to Dielectric Screening in Solvents with Explicit Expressions for the Screening Energy and Its Gradient. J Chem. Soc.-Perkin Transactions 2799 (1993).

[84] S.F. Boys, F. Bernardi: The Calculation of Small Molecular Interactions by the Differences of Separate Total Energies. Some Procedures with Reduced Errors. Mol. Phys. 19553 (1970). 
[85] T. Zimmermann, J.V. Burda: Cisplatin Interaction with Cysteine and Methionine in Aqueous Solution: Computational DFT/PCM Study. J. Comput. Chem. (2008).

[86] J. Šponer, M. Sabat, J.V. Burda, A.M. Doody, J. Leszczynski, P. Hobza: Stabilization of the Purine.Purine.Pyrimidine DNA Base Triplets by Divalent Metal Cations. J. Biomol. Structure Dynamics 16139 (1998).

[87] A.E. Reed, R.B. Weinstock, F. Weinhold: Natural population analysis. J. Chem. Phys. 83735 (1985).

[88] M.J. Frisch, J.A. Pople, J.S. Binkley: Self-Consistent Molecular Orbital Methods 25. Supplementary Functions for Gaussian Basis Sets. J. Chem. Phys. 803265 (1984).

[89] F. Weinhold, NBO 5.0 Program University of Wisconsin, Madison, Wisconsin 53706, Wisconsin, 2001.

[90] R.F.W. Bader: Atoms in Molecules: A Quantum Theory, Oxford Univ. Press, Oxford, 1990.

[91] G. Schaftenaar, J.H. Noordik: Molden: a pre- and post-processing program

for molecular and electronic structures. J. Comput.-Aided Mol. Design 14123 (2000).

[92] P.F. Flükiger: Development of the molecular graphics package MOLEKEL and its application to selected problems in organic and organometallic chemistry, Thèse No 2561, Département de chimie physique, Université de Genève, 1992. http://www.cscs.ch/molekel/.

[93] S. Portmann, H.P. Lüthi: MOLEKEL: An Interactive Molecular Graphics Tool. Chimia 54766 (2000).

[94] U. Ryde, M.H.M. Olsson, K. Pierloot, B.O. Roos: J. Mol. Biol. 261586 (1996).

[95] D.W. Randall, S.D. George, P.L. Holland, B. Hedman, K.O. Hodgson, W.B. Tolman, E.I. Solomon: Spectroscopic and Electronic Structural Studies of Blue Copper Model Complexes. 2. Comparison of Three- and FourCoordinate $\mathrm{Cu}(\mathrm{II})-$ Thiolate Complexes and Fungal Laccase. J. Am. Chem. Soc. 12211632 (2000).

[96] E.I. Solomon, K.W. Penfield, A.A. Gewirth, e. al: Electronic structure of the oxidized and reduced blue copper sites: Contributions to the electron transfer pathway, reduction potential, and geometry. Inorg. Chim. Acta 24367 (1996).

[97] S.N. Datta, J. Sudhamsu, A. Pandey: Theoretical determination of the standard reduction potential of plastocyanin in vitro. J. Phys. Chem. B 1088007 (2004).

[98] R.G. Parr, R.G. Pearson: HSAB. J. Am. Chem. Soc. 1057512 (1983).

[99] H. Li, S.P. Webb, J. Ivanic, J.H. Jensen: Determinants of the Relative Reduction Potentials of Type-1

Copper Sites in Proteins. J. Am. Chem. Soc. 1268010 (2004).

[100] J.A.O. De Kerpel, K. Pierloot, U. Ryde, B.O. Roos: Theoretical Study of the Structural and Spectroscopic Properties of Stellacyanin. J. Phys. Chem. B 102 4638 (1998). 
Table 1. Coordination distances for oxidized $\mathrm{Cu}(\mathrm{II})$ and reduced $\mathrm{Cu}(\mathrm{I})$ complexes of the $\mathrm{A}$ and $\mathrm{B}$ centers of blue copper proteins (in $\AA$ ). Bond lengths for structures obtained in both constrained and full optimization are presented. The optimizations were performed in vacuo, protein-like, and water environment. Bold indicates the averaged PDB distances, which are not changed in the optimization phase I.

\begin{tabular}{|c|c|c|c|c|c|c|c|}
\hline & \multicolumn{3}{|c|}{ Oxidized Type A center } & \multicolumn{3}{|c|}{ Oxidized Type B center } \\
\hline & & in vacuc & cotein-like & water & in vacu & otein-like & water \\
\hline \multirow{2}{*}{$\mathrm{Cu}-\mathrm{S}(\mathrm{Cys})$} & Constr. opt & & 2.204 & & & 2.196 & \\
\hline & Full opt. & 2.184 & 2.204 & 2.230 & 2.252 & 2.262 & 2.270 \\
\hline \multirow{2}{*}{$\mathrm{Cu}-\mathrm{N}(\mathrm{His})$} & Constr. opt & & 1.948 & & & 1.947 & \\
\hline & Full opt. & 2.036 & 2.021 & 2.019 & 2.042 & 2.027 & 2.022 \\
\hline \multirow{2}{*}{$\mathrm{Cu}-\mathrm{N}(\mathrm{His})$} & Constr. opt & & 2.043 & & & 2.035 & \\
\hline & Full opt. & 2.054 & 2.034 & 2.026 & 2.059 & 2.039 & 2.032 \\
\hline \multirow{3}{*}{$\begin{array}{l}\mathrm{Cu}-\mathrm{S}(\mathrm{Met}) / \\
\mathrm{Cu}-\mathrm{O}(\mathrm{Gln})\end{array}$} & Constr. opt & & 2.889 & & & 2.190 & \\
\hline & Full opt. & 2.567 & 2.535 & 2.494 & 2.043 & 2.039 & 2.034 \\
\hline & & $\begin{array}{r}\text { Redu } \\
\text { in vacuc }\end{array}$ & $\begin{array}{l}\text { d Type A } \\
\text { rotein-like }\end{array}$ & $\begin{array}{l}\text { enter } \\
\text { water }\end{array}$ & $\begin{array}{r}\text { Red } \\
\text { in vacu }\end{array}$ & $\begin{array}{l}\text { T.pe B c } \\
\text { otein-like }\end{array}$ & $\begin{array}{l}\text { nter } \\
\text { water }\end{array}$ \\
\hline \multirow{2}{*}{$\mathrm{Cu}-\mathrm{S}(\mathrm{Cys})$} & Constr. opt & & 2.190 & & & 2.198 & \\
\hline & Full opt. & 2.190 & 2.211 & 2.218 & 2.199 & 2.218 & 2.226 \\
\hline \multirow{2}{*}{$\mathrm{Cu}-\mathrm{N}(\mathrm{His})$} & Constr. opt & & 1.969 & & & 2.014 & \\
\hline & Full opt. & 1.995 & 2.063 & 2.106 & 2.031 & 2.032 & 2.030 \\
\hline \multirow{2}{*}{$\mathrm{Cu}-\mathrm{N}$ (His) } & Constr. opt & & 2.098 & & & 2.069 & \\
\hline & Full opt. & 2.225 & 2.066 & 2.027 & 2.131 & 2.090 & 2.082 \\
\hline $\mathrm{Cu}-\mathrm{S}(\mathrm{Met}) /$ & Constr. opt & & 2.852 & & & 2.284 & \\
\hline $\mathrm{Cu}-\mathrm{O}(\mathrm{Gln})$ & Full opt. & 4.430 & 4.662 & 4.974 & 3.728 & 3.854 & 3.845 \\
\hline
\end{tabular}

Table 2. Average $\mathrm{Cu}-\mathrm{X} \quad(\mathrm{S}, \mathrm{O}, \mathrm{N})$ bond lengths (in $\AA$ ) for small $\left[\mathrm{Cu}\left(\mathrm{H}_{2} \mathrm{~S}\right)_{\mathrm{m}}\left(\mathrm{H}_{2} \mathrm{O}\right)_{\mathrm{n}}\left(\mathrm{NH}_{3}\right)_{\mathrm{k}}\right]^{2+/+}$ models[79] and corresponding values obtained from CSD database by Katz et al.[23].

\begin{tabular}{|c|ccc|ccc|}
\hline $\mathbf{C u}(\mathbf{I I})$ & \multicolumn{3}{|c|}{ Small models } & \multicolumn{3}{c|}{ CSD } \\
& 4-coord. & 5-coord. & 6-coord. & 4-coord. & 5-coord. & 6-coord. \\
\hline $\mathrm{Cu}-\mathrm{N}$ & 2.03 & 2.09 & 2.28 & 1.98 & 2.03 & 2.34 \\
$\mathrm{Cu}-\mathrm{O}$ & 2.01 & 2.06 & 2.13 & 1.93 & 2.07 & 2.36 \\
$\mathrm{Cu}-\mathrm{S}$ & 2.40 & 2.49 & 2.41 & 2.28 & 2.43 & 2.72 \\
\hline $\mathrm{Cu}(\mathbf{I})$ & \multicolumn{3}{|c|}{ Small models } & & $\mathrm{CSD}$ & \\
& 2-coord. & 3-coord. & 4-coord. & 2-coord. & 3-coord. & 4-coord. \\
\hline $\mathrm{Cu}-\mathrm{N}$ & 1.91 & 2.02 & 2.12 & 1.90 & 1.98 & 2.04 \\
$\mathrm{Cu}-\mathrm{O}$ & 1.88 & 2.04 & 2.21 & 1.84 & 2.14 & 2.05 \\
$\mathrm{Cu}-\mathrm{S}$ & 2.19 & 2.29 & 2.35 & 2.17 & 2.26 & 2.33 \\
\hline
\end{tabular}


Table 3. $\Delta \boldsymbol{E}^{\text {stab }}$ stabilization and $\boldsymbol{\Delta} \boldsymbol{E}^{\boldsymbol{T C} \boldsymbol{E}}$ sterically corrected stabilization energies (in $\mathrm{kcal} / \mathrm{mol}$ ) for oxidized $\mathrm{Cu}(\mathrm{II})$ and reduced $\mathrm{Cu}(\mathrm{I})$ complexes of the $\mathrm{A}$ and $\mathrm{B}$ centers of blue copper proteins. Energies are presented for structures obtained by all optimization schemes with and without environment effects.

\begin{tabular}{|c|c|c|c|c|c|c|c|}
\hline & \multicolumn{3}{|c|}{ Oxidized Type A center } & \multicolumn{3}{|c|}{ Oxidized Type B center } \\
\hline & & in vacuo & protein-like & water & in vacuo & protein-like & water \\
\hline \multirow{2}{*}{$\Delta E^{s t a b}$} & Constr. opt & 589.9 & 330.3 & 256.7 & 595.4 & 332.3 & 258.2 \\
\hline & Full opt. & 596.4 & 336.3 & 263.3 & 602.0 & 339.0 & 265.1 \\
\hline \multirow{2}{*}{$\Delta E^{T C E}$} & Constr. opt & 616.9 & 372.6 & 298.7 & 631.2 & 383.9 & 308.1 \\
\hline & Full opt. & 619.7 & 380.4 & 309.8 & 623.9 & 384.5 & 308.4 \\
\hline & & \multicolumn{3}{|c|}{ Reduced Type A center } & \multicolumn{3}{|c|}{ Reduced Type B center } \\
\hline & & in vacuo & protein-like & water & in vacuo & protein-like & water \\
\hline \multirow{2}{*}{$\Delta E^{s t a b}$} & Constr. opt & 229.4 & 125.1 & 96.9 & 229.4 & 123.9 & 95.0 \\
\hline & Full opt. & 242.0 & 132.9 & 104.6 & 250.9 & 138.4 & 106.9 \\
\hline \multirow{2}{*}{$\triangle E^{T C E}$} & Constr. opt & 254.6 & 165.9 & 137.5 & 258.3 & 169.3 & 140.6 \\
\hline & Full opt. & 254.9 & 166.2 & 134.9 & 254.3 & 164.9 & 131.2 \\
\hline
\end{tabular}

Table 4. $\Delta \boldsymbol{E}^{\boldsymbol{B} \boldsymbol{E}}$ bond energies (in $\mathrm{kcal} / \mathrm{mol}$ ) for oxidized $\mathrm{Cu}(\mathrm{II})$ and reduced $\mathrm{Cu}(\mathrm{I})$ complexes of the $\mathrm{A}$ and $\mathrm{B}$ centers in various environments.

\begin{tabular}{|c|c|c|c|c|c|c|c|}
\hline & \multicolumn{3}{|c|}{ Oxidized type A center } & \multicolumn{3}{|c|}{ Oxidized type B center } \\
\hline & & in vacuc & otein lik & water & in vacuc & otein lik & water \\
\hline \multirow{2}{*}{$\mathrm{Cu}-\mathrm{S}(\mathrm{Cys})$} & Constr. opt & 242.6 & 105.4 & 65.2 & 238.7 & 108.7 & 75.5 \\
\hline & Full opt. & 240.1 & 100.2 & 56.7 & 234.2 & 96.3 & 70.2 \\
\hline \multirow{2}{*}{$\mathrm{Cu}-\mathrm{N}(\mathrm{His})$} & Constr. opt & 31.5 & 26.0 & 24.4 & 28.9 & 22.5 & 21.4 \\
\hline & Full opt. & 33.6 & 25.5 & 19.7 & 33.3 & 27.0 & 30.3 \\
\hline \multirow{2}{*}{$\mathrm{Cu}-\mathrm{N}(\mathrm{His})$} & Constr. opt & 35.7 & 24.3 & 22.6 & 28.9 & 22.2 & 21.1 \\
\hline & Full opt. & 28.4 & 20.8 & 22.2 & 28.4 & 21.0 & 23.0 \\
\hline \multirow{4}{*}{$\begin{array}{l}\mathrm{Cu}-\mathrm{S}(\mathrm{Met}) \\
\mathrm{Cu}-\mathrm{O}(\mathrm{Gln})\end{array}$} & Constr. opt & 4.6 & 0.0 & -1.0 & 10.9 & 2.4 & 0.6 \\
\hline & Full opt. & 13.2 & 8.9 & 10.1 & 20.3 & 23.9 & 25.8 \\
\hline & & Redu & type $A$ & nter & Red & type B & nter \\
\hline & & in vacuc & otein lil & water & in vacuc & otein lik & water \\
\hline \multirow{2}{*}{$\mathrm{Cu}-\mathrm{S}(\mathrm{Cys})$} & Constr. opt & 109.2 & 41.0 & 23.2 & 106.8 & 39.6 & 22.4 \\
\hline & Full opt. & 130.6 & 54.7 & 42.8 & 131.7 & 57.3 & 43.0 \\
\hline \multirow{2}{*}{$\mathrm{Cu}-\mathrm{N}$ (His) } & Constr. opt & 8.2 & 6.6 & 7.2 & 5.7 & 3.8 & 4.7 \\
\hline & Full opt. & 22.5 & 12.3 & 24.3 & 20.6 & 16.7 & 21.1 \\
\hline \multirow{2}{*}{$\mathrm{Cu}-\mathrm{N}$ (His) } & Constr. opt & 3.7 & 1.9 & 2.5 & 3.2 & 0.2 & 0.9 \\
\hline & Full opt. & 5.9 & 10.9 & 5.9 & 10.0 & 8.7 & 11.5 \\
\hline $\mathrm{Cu}-\mathrm{S}(\mathrm{Met})$ & Constr. opt & -2.2 & -4.9 & -5.4 & -1.5 & -6.8 & -7.4 \\
\hline $\mathrm{Cu}-\mathrm{O}(\mathrm{Gln})$ & Full opt. & 3.7 & -4.1 & -2.7 & 15.8 & 3.1 & -4.7 \\
\hline
\end{tabular}


Table 5. Vertical and adiabatic ionization potentials (in $\mathrm{eV}$ ) representing transition from reduced to oxidized state. Values are presented for both the A and B centers obtained in vacuo as well as in protein-like and water environment.

\begin{tabular}{|c|c|ccc|ccc|}
\hline & & \multicolumn{3}{|c|}{ Vertical ionization } & \multicolumn{3}{c|}{ Adiabatic ionization } \\
& Center & in vacuo & protein-like & water & in vacuo & protein-like & water \\
\hline \multirow{2}{*}{ Constr. opt. } & A & 5.03 & 4.29 & 4.15 & 4.97 & 4.23 & 4.08 \\
& B & 4.85 & 4.13 & 4.00 & 4.73 & 4.04 & 3.93 \\
Full opt. & A & 5.92 & 5.08 & 4.92 & 5.22 & 4.30 & 4.33 \\
& B & 6.03 & 5.27 & 5.06 & 5.36 & 4.39 & 4.13 \\
\hline
\end{tabular}

Table 6. Redox potentials (in $\mathrm{mV}$ ) for selected blue copper proteins[12].

\begin{tabular}{|c|c|c|}
\hline \multicolumn{2}{|c|}{ protein } & redox potential \\
\hline & amicyanin & 261 \\
& auracyanin & 240 \\
Type A & plastocyanin & 370 \\
& rusticyanin & 680 \\
& averaged & $\mathbf{3 8 8}$ \\
\hline \multirow{5}{*}{ Type B } & mavicyanin & 285 \\
& stellacyanin & 184 \\
& umecyanin & 283 \\
& averaged & $\mathbf{2 5 1}$ \\
\hline
\end{tabular}


Table 7. Spin electron density (in e) localized on copper, cysteine model, and the rest of complex obtained by the NPA method for oxidized $\mathrm{Cu}$ (II) complexes of the A and B centers.

\begin{tabular}{|c|c|c|c|c|c|}
\hline & \multicolumn{3}{|c|}{ Spin density } \\
\hline & & & $\mathrm{Cu}$ & $\mathrm{S}(\mathrm{Cys})$ & $\mathrm{N}, \mathrm{N}, \mathrm{S} / \mathrm{O}$ \\
\hline \multirow{6}{*}{$\begin{array}{l}\text { Type A } \\
\text { center }\end{array}$} & \multirow{2}{*}{ in vacuo } & Constr. opt & 0.34 & 0.56 & 0.09 \\
\hline & & Full opt. & 0.38 & 0.50 & 0.12 \\
\hline & \multirow{2}{*}{ protein-like } & Constr. opt & 0.40 & 0.48 & 0.12 \\
\hline & & Full opt. & 0.44 & 0.39 & 0.18 \\
\hline & \multirow{2}{*}{ water } & Constr. opt & 0.43 & 0.44 & 0.13 \\
\hline & & Full opt. & 0.48 & 0.32 & 0.20 \\
\hline \multirow{6}{*}{$\begin{array}{l}\text { Type B } \\
\text { center }\end{array}$} & \multirow{2}{*}{ in vacuo } & Constr. opt & 0.39 & 0.51 & 0.10 \\
\hline & & Full opt. & 0.53 & 0.30 & 0.17 \\
\hline & \multirow{2}{*}{ protein-like } & Constr. opt & 0.47 & 0.41 & 0.13 \\
\hline & & Full opt. & 0.56 & 0.25 & 0.19 \\
\hline & \multirow{2}{*}{ water } & Constr. opt & 0.50 & 0.36 & 0.14 \\
\hline & & Full opt. & 0.57 & 0.23 & 0.19 \\
\hline
\end{tabular}

Table 8. Partial atomic charges (in e) on copper and coordinated atoms $\mathrm{S}(\mathrm{Cys})$, $\mathrm{N}(\mathrm{His}), \mathrm{S}(\mathrm{Met})$, and $\mathrm{O}(\mathrm{Gln})$ obtained by the NPA method.

\begin{tabular}{|c|c|c|c|c|c|c|c|}
\hline & \multicolumn{3}{|c|}{ Oxidized Type A center } & \multicolumn{3}{|c|}{ Oxidized Type B center } \\
\hline & & in vacuc & otein-like & water & in vacuo & otein-like & water \\
\hline \multirow{2}{*}{$\mathrm{Cu}$} & Constr. opt & 0.961 & 1.016 & 1.043 & 1.042 & 1.110 & 1.140 \\
\hline & Full opt. & 0.976 & 1.032 & 1.059 & 1.166 & 1.197 & 1.208 \\
\hline \multirow{2}{*}{$\mathrm{S}(\mathrm{Cys})$} & Constr. opt & -0.130 & -0.225 & -0.272 & -0.174 & -0.292 & -0.346 \\
\hline & Full opt. & -0.209 & -0.312 & -0.387 & -0.350 & -0.424 & -0.457 \\
\hline \multirow{2}{*}{$\mathrm{N}(\mathrm{His})$} & Constr. opt & -0.634 & -0.650 & -0.655 & -0.625 & -0.651 & -0.656 \\
\hline & Full opt. & -0.639 & -0.661 & -0.646 & -0.645 & -0.639 & -0.658 \\
\hline \multirow{2}{*}{$\mathrm{N}($ His $)$} & Constr. opt & -0.652 & -0.657 & -0.661 & -0.644 & -0.643 & -0.649 \\
\hline & Full opt. & -0.632 & -0.642 & -0.665 & -0.628 & -0.655 & -0.643 \\
\hline \multirow{2}{*}{$\begin{array}{l}\mathrm{S} \text { (Met)/ } \\
\mathrm{O}(\mathrm{Gln})\end{array}$} & Constr. opt & 0.190 & 0.184 & 0.183 & -0.738 & -0.755 & -0.770 \\
\hline & Full opt. & 0.225 & 0.237 & 0.258 & -0.762 & -0.770 & -0.775 \\
\hline & & \multicolumn{3}{|c|}{ Reduced Type A center } & \multicolumn{3}{|c|}{ Reduced Type B center } \\
\hline & & in vacuo & otein-like & water & in vacuo & otein-like & water \\
\hline \multirow{2}{*}{$\mathrm{Cu}$} & Constr. opt & 0.697 & 0.712 & 0.715 & 0.737 & 0.750 & 0.752 \\
\hline & Full opt. & 0.648 & 0.687 & 0.686 & 0.675 & 0.693 & 0.698 \\
\hline \multirow{2}{*}{ S(Cys) } & Constr. opt & -0.573 & -0.647 & -0.678 & -0.570 & -0.652 & -0.684 \\
\hline & Full opt. & -0.561 & -0.633 & -0.659 & -0.546 & -0.624 & -0.654 \\
\hline \multirow[t]{2}{*}{$\mathrm{N}($ His $)$} & Constr. opt & -0.594 & -0.613 & -0.626 & -0.590 & -0.623 & -0.635 \\
\hline & Full opt. & -0.598 & -0.622 & -0.628 & -0.586 & -0.623 & -0.635 \\
\hline \multirow[t]{2}{*}{$\mathrm{N}($ His $)$} & Constr. opt & -0.604 & -0.630 & -0.643 & -0.603 & -0.616 & -0.631 \\
\hline & Full opt. & -0.582 & -0.622 & -0.637 & -0.603 & -0.614 & -0.651 \\
\hline $\mathrm{S}($ Met $) /$ & Constr. opt & 0.223 & 0.205 & 0.197 & -0.676 & -0.708 & -0.735 \\
\hline $\mathrm{O}(\mathrm{Gln})$ & Full opt. & 0.194 & 0.185 & 0.184 & -0.718 & -0.732 & -0.742 \\
\hline
\end{tabular}


Table 9. EPR g-factors for all studied $\mathrm{Cu}$ (II) centers (in a.u.). Experimental values taken from ref.[12].

\begin{tabular}{|cl|c|cc|cc|cc|}
\hline & & Exp. & \multicolumn{2}{|c|}{ in vacuo } & \multicolumn{2}{c|}{ protein-like } & \multicolumn{2}{c|}{ water } \\
& & & Constr. & Full opt. & Constr. & Full opt. & Constr. & Full opt. \\
\hline Type & $\mathrm{g}_{\|}$ & 2.226 & 2.115 & 2.131 & 2.131 & 2.137 & 2.138 & 2.143 \\
$\mathrm{~A}$ & $\mathrm{~g} \perp_{\perp}$ & 2.045 & 2.052 & 2.056 & 2.058 & 2.061 & 2.061 & 2.065 \\
\hline Type & $\mathrm{g}_{\|}$ & 2.297 & 2.123 & 2.085 & 2.140 & 2.090 & 2.147 & 2.120 \\
$\mathrm{~B}$ & $\mathrm{~g} \perp$ & 2.051 & 2.058 & 2.079 & 2.066 & 2.082 & 2.070 & 2.073 \\
\hline
\end{tabular}




\section{Captions to Figures:}

Figure 1: PDB structure of plastocyanin (1KDI).

Figure 2: Models of $\boldsymbol{a}$ ) Type A and $\boldsymbol{b}$ ) Type B centers of blue copper proteins. Family of Type A centers includes following peptides: amicyanin, auracyanin, plastocyanin, and rusticyanin. In case of the Type B centers, following proteins were considered: mavicyanin, stellacyanin, and umecyanin.

Figure 3: Example of 4-coordinated $\left[\mathrm{Cu}\left(\mathrm{H}_{2} \mathrm{~S}\right)_{2}\left(\mathrm{NH}_{3}\right)_{2}\right]^{2+}$ complex, where transition from $\mathrm{Cu}$ (II) to $\mathrm{Cu}$ (I) state goes along with pronounced structural change from squareplanar to tetrahedral ligand arrangement. When the system is even more relaxed, it evolves to 2-coordinated structure.

Figure 4: Structures of reduced $\boldsymbol{a}$ ) Type A and $\boldsymbol{b}$ ) Type B centers after the full optimization in vacuo. Optimized structure of oxidized centers of $\boldsymbol{c}$ ) Type A and $\boldsymbol{d}$ ) Type B are presented too.

Figure 5: The relaxation energies (in $\mathrm{kcal} / \mathrm{mol}$ ), determined as relative differences of $\Delta \boldsymbol{E}^{\text {Stab }}$ energies of constrained and fully optimized structures for:

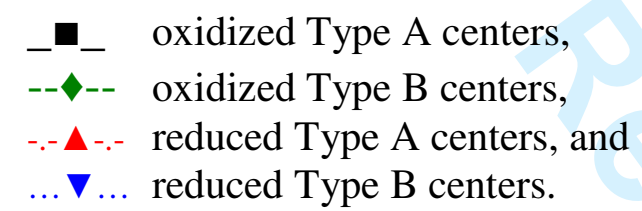

Figure 6: Plots of spin isodensities $\left(\rho_{\mathrm{s}}=0.01 \mathrm{e} / \AA^{3}\right)$ for selected $\mathrm{Cu}$ (II) complexes. Oxidized $\boldsymbol{a}$ ) Type A (plastocyanin) and $\boldsymbol{b}$ ) Type B (umecyanin) centers with imposed protein geometry (constrained opt.) and $\boldsymbol{c}$ ) Type A and $\boldsymbol{d}$ ) Type B centers after full optimization are considered.

Figure 7: Three different schemes of SOMO with examples. The a) scheme occurs in Type A centers (opt. phase I), b) scheme is in Type A (full opt.) and Type B (opt. phase I) complexes, and $\boldsymbol{c}$ ) can be found in fully optimized Type B center. 


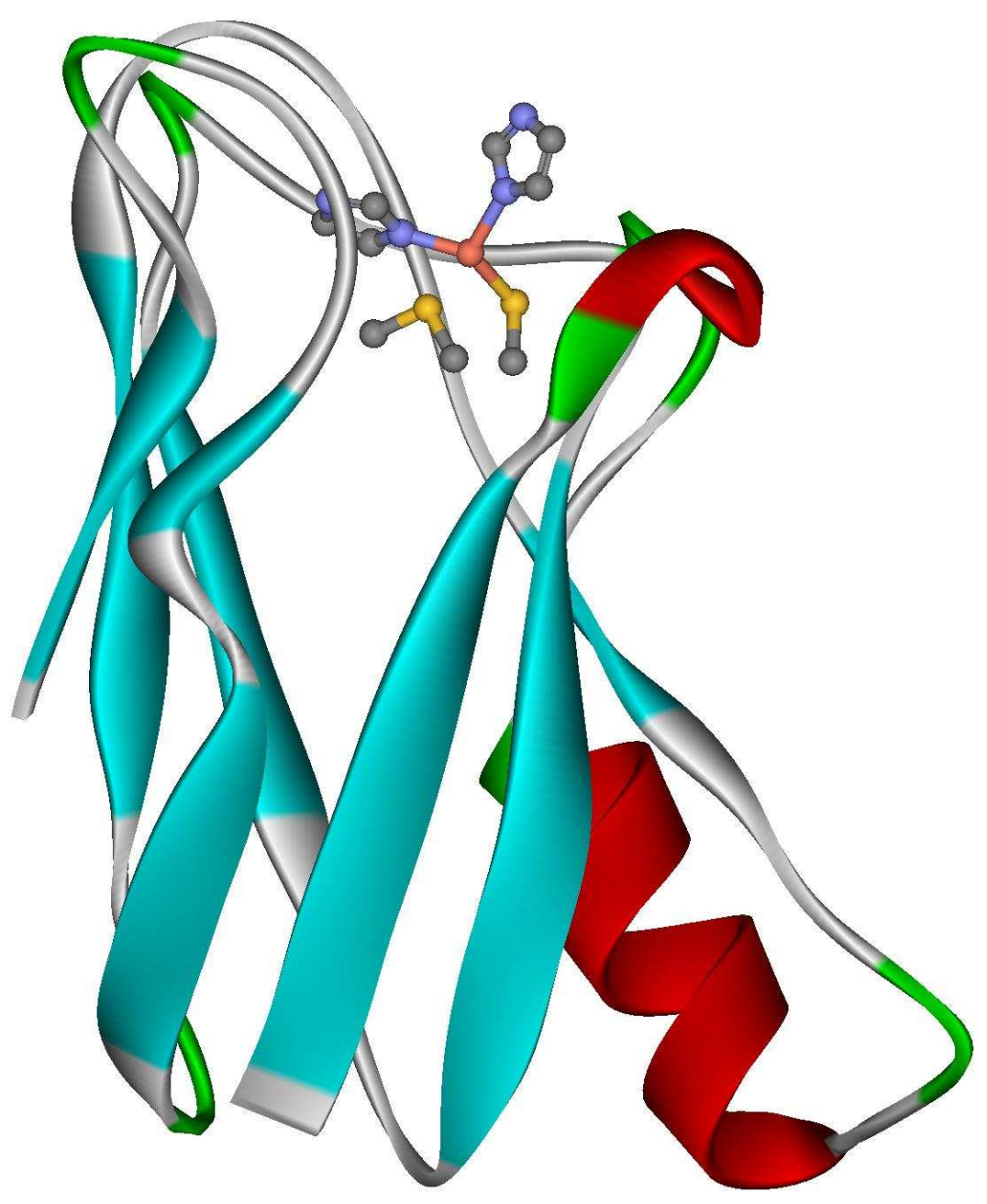

Figure 1: 
Molecular Physics

Page 40 of 45

1
2
3
4
5
6
7
8
9
9
10
11
12
13
14
15
16
17
18
19
20
21
22
23
24
25
26
26
27
28
29
30
31
32
33
3
34
35
36
37
38
39
40
41
42
4
4
4
4
5

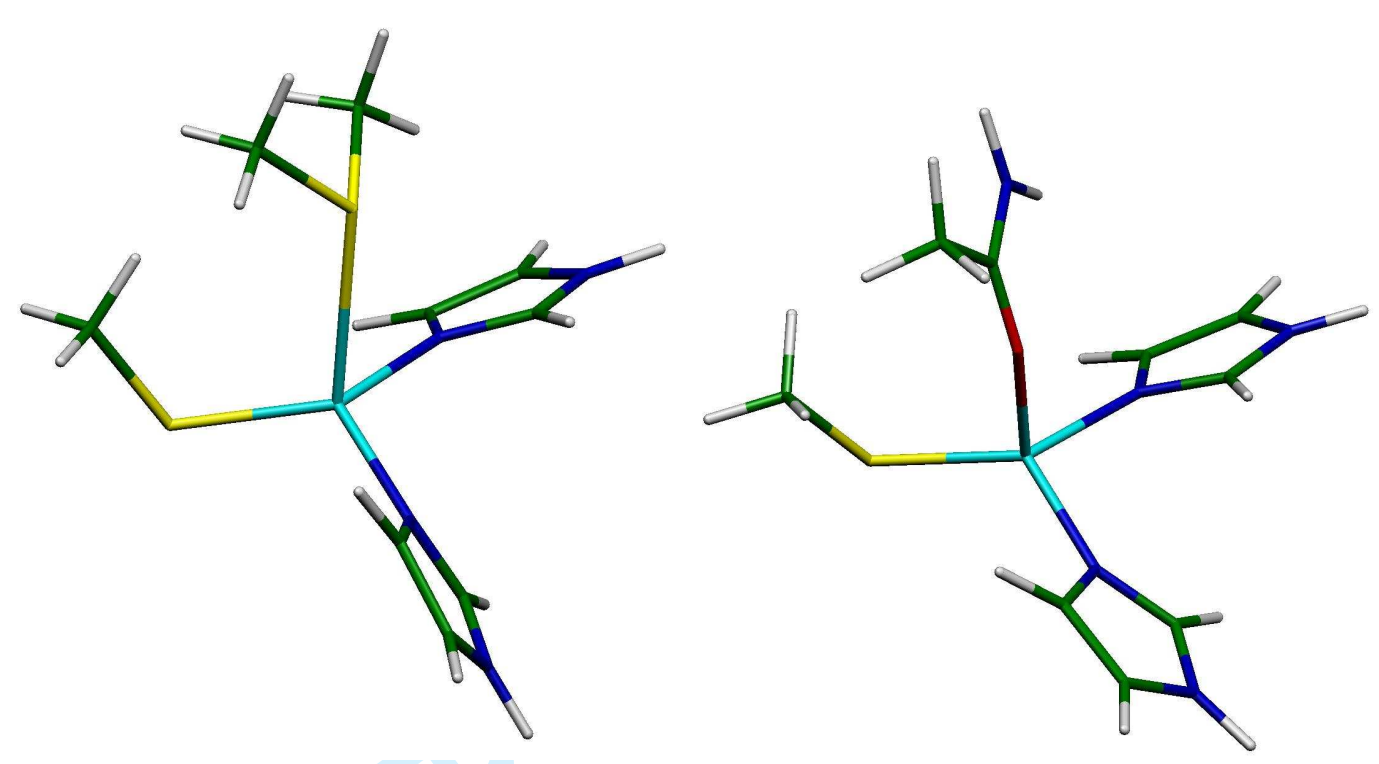

Figure 2

URL: http://mc.manuscriptcentral.com/tandf/tmph 


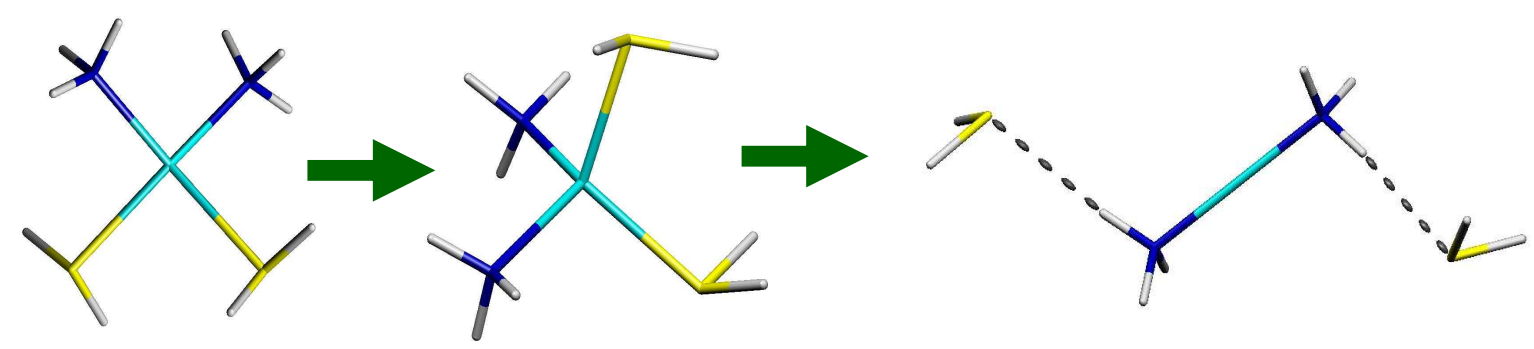

Figure 3 


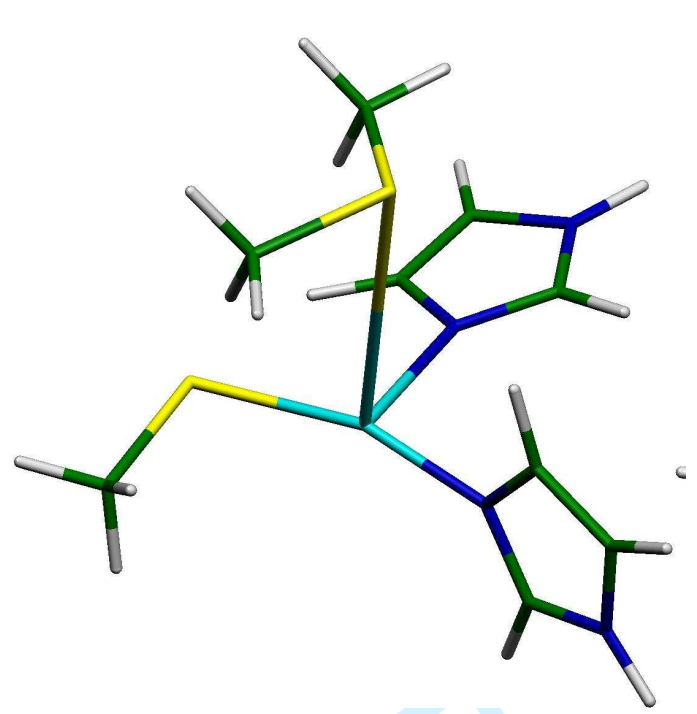

a)

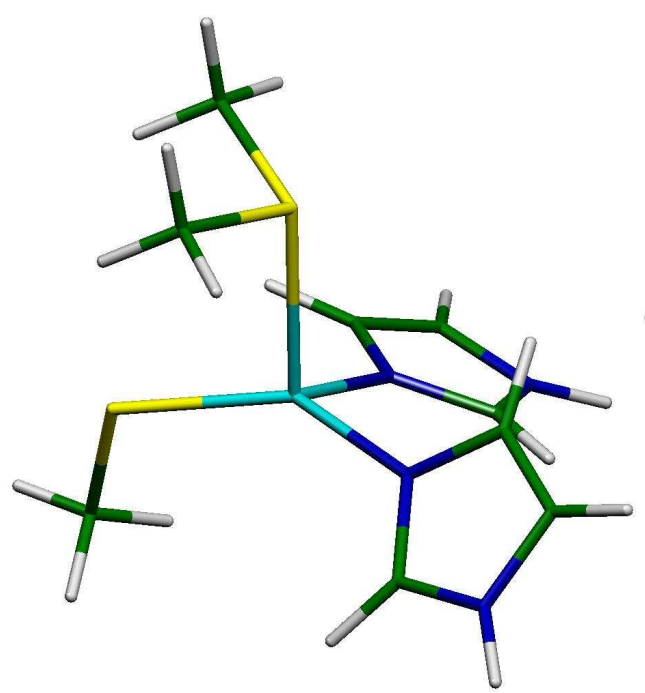

c)

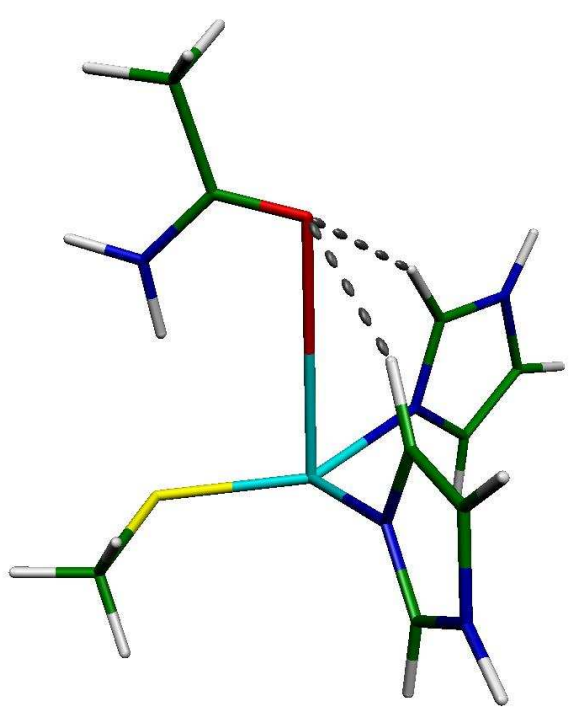

b)

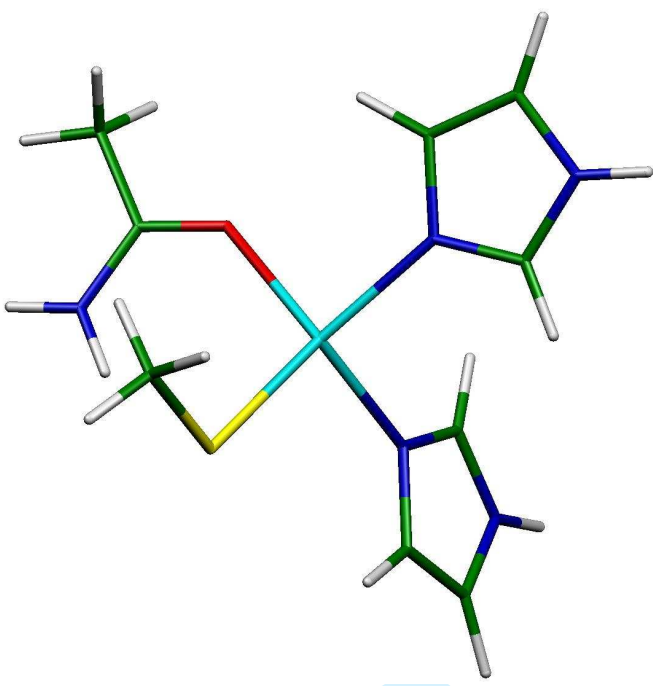

d)

Figure 4 


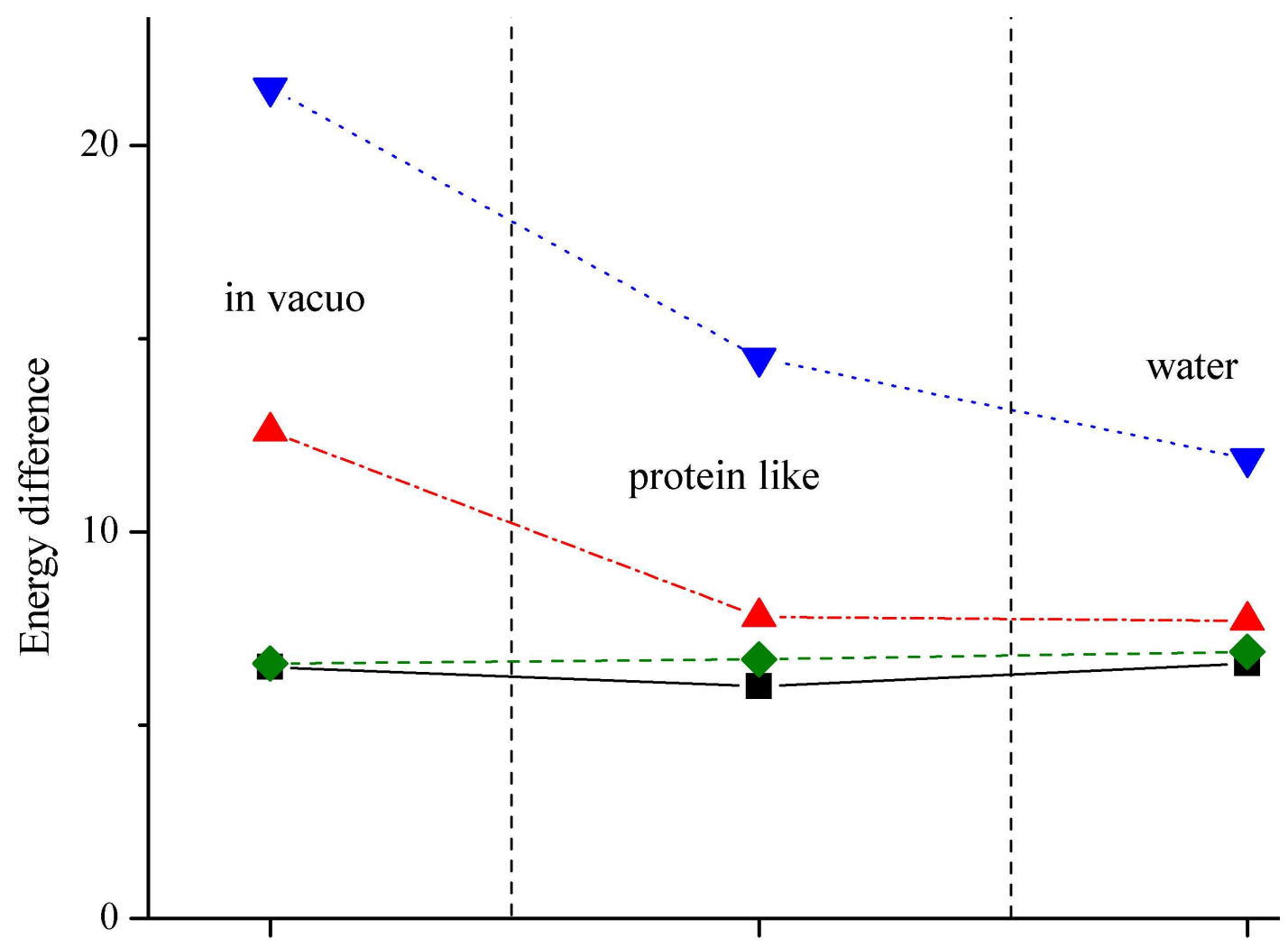

Figure 5 


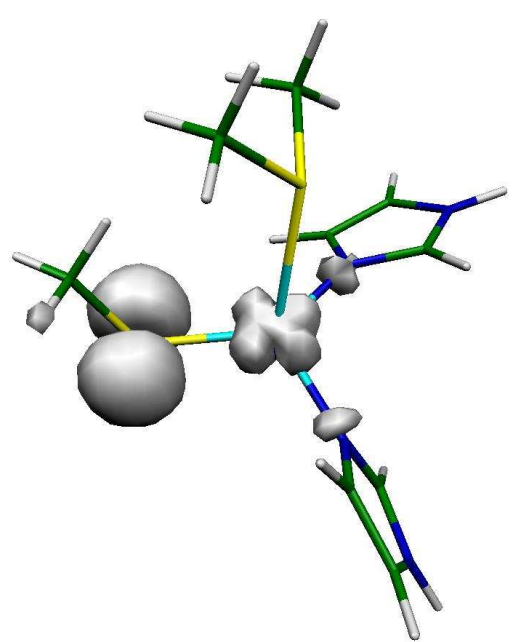

a)

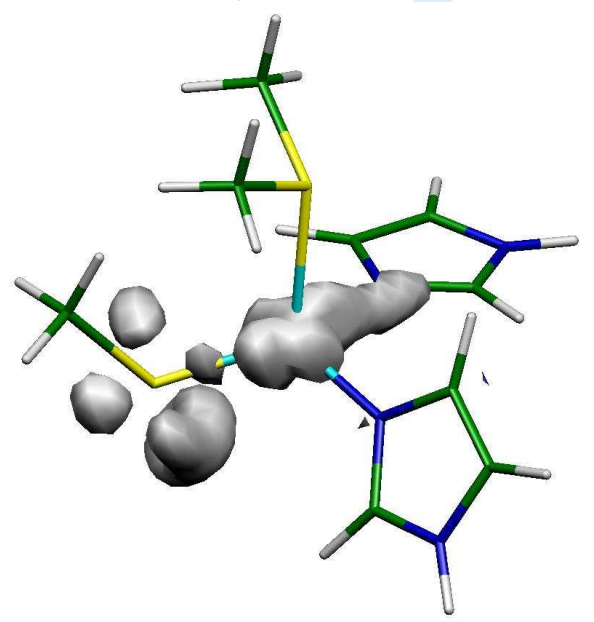

c)

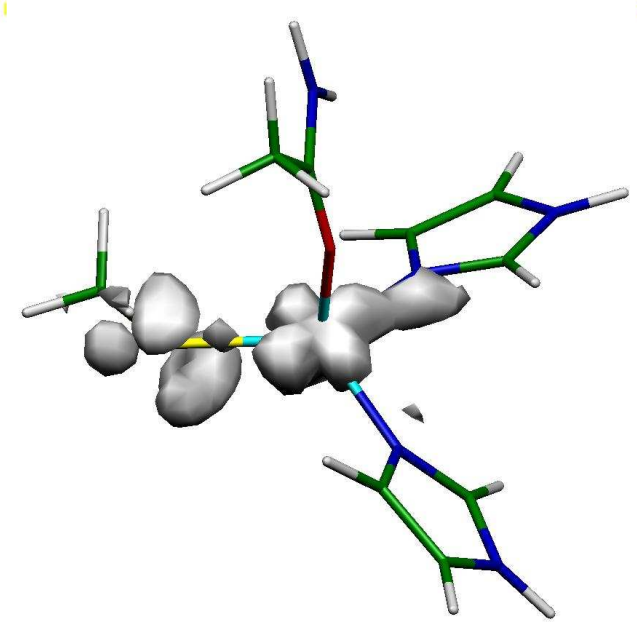

b)

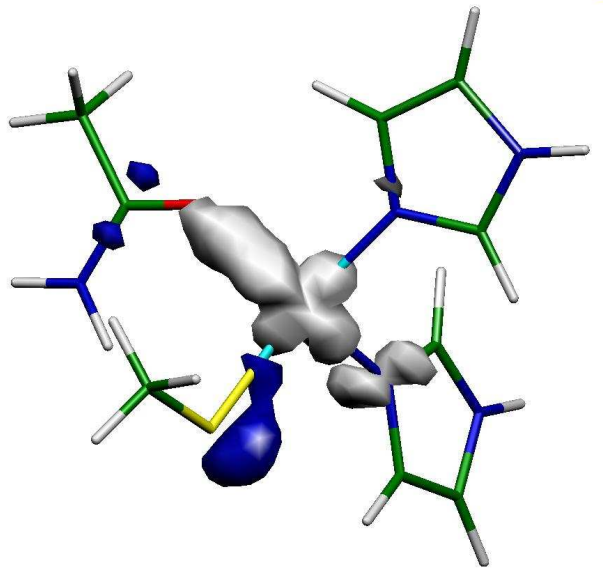

d)

Figure 6 
a)

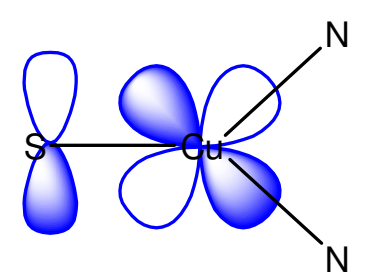

b)
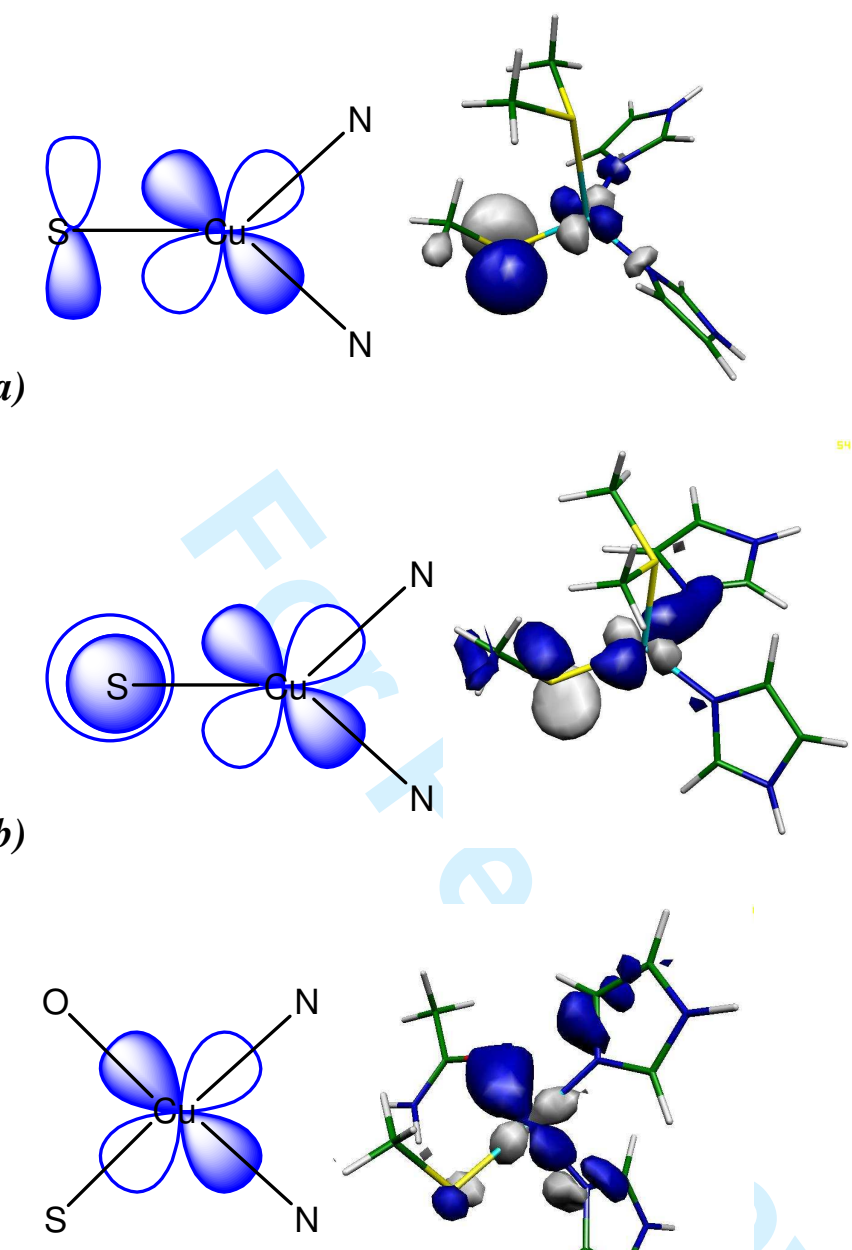

c)

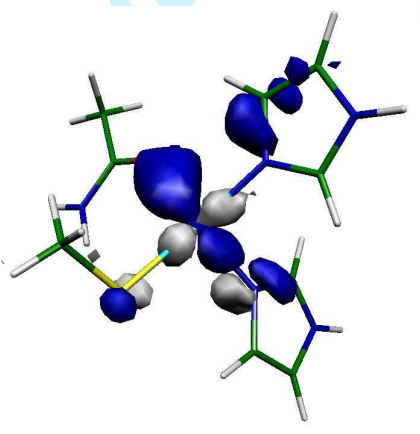

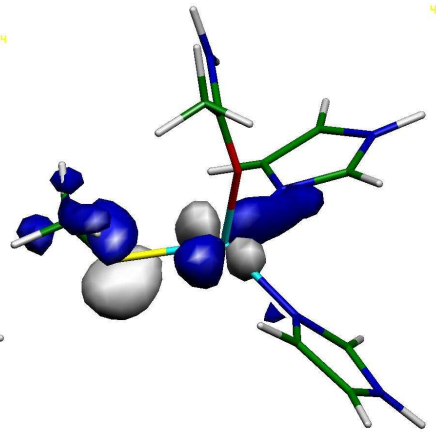

Figure 7 